\title{
LEVEL II SCOUR ANALYSIS FOR BRIDGE 8 (SALITH00010008) on TOWN HIGHWAY 1, crossing OTTER CREEK, SALISBURY, VERMONT
}

Open-File Report 98-536

Prepared in cooperation with

VERMONT AGENCY OF TRANSPORTATION

and

FEDERAL HIGHWAY ADMINISTRATION

U.S. Department of the Interior

U.S. Geological Survey

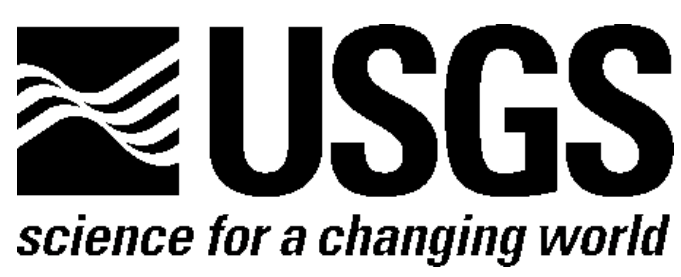




\section{LEVEL II SCOUR ANALYSIS FOR BRIDGE 8 (SALITH00010008) on TOWN HIGHWAY 1, crossing OTTER CREEK, SALISBURY, VERMONT \\ By ERICK M. BOEHMLER AND LAURA MEDALIE}

U.S. Geological Survey Open-File Report 98-536

Prepared in cooperation with

VERMONT AGENCY OF TRANSPORTATION and

FEDERAL HIGHWAY ADMINISTRATION 


\title{
U.S. DEPARTMENT OF THE INTERIOR BRUCE BABBITT, Secretary
}

\author{
U.S. GEOLOGICAL SURVEY
}

Thomas J. Casadevall, Acting Director

For additional information write to:

District Chief

U.S. Geological Survey 361 Commerce Way

Pembroke, NH 03275-3718
Copies of this report may be purchased from:

U.S. Geological Survey

Branch of Information Services

Open-File Reports Unit

Box 25286

Denver, CO 80225-0286 


\section{CONTENTS}

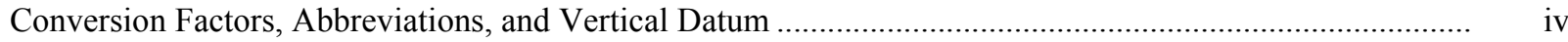

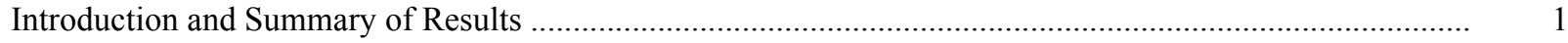

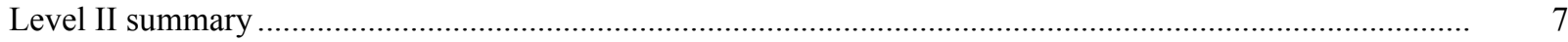

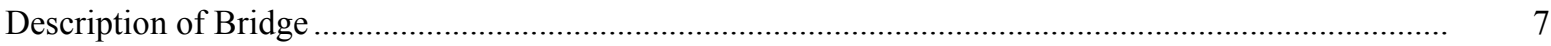

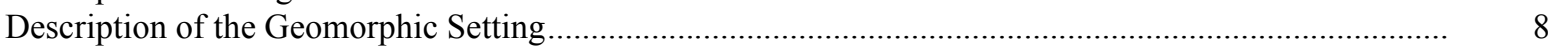

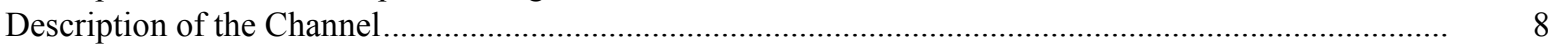

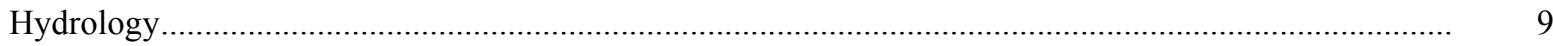

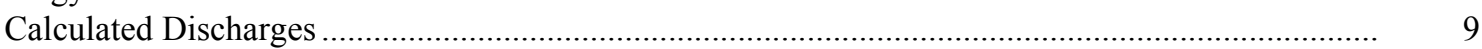

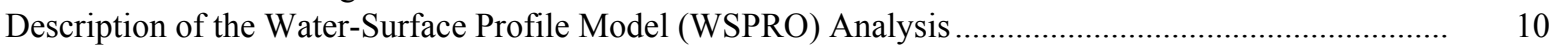

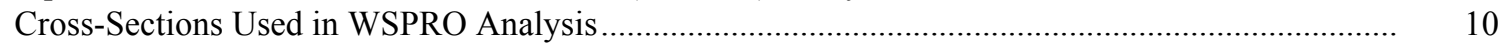

Data and Assumptions Used in WSPRO Model ......................................................................... 11

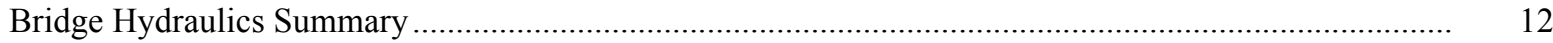

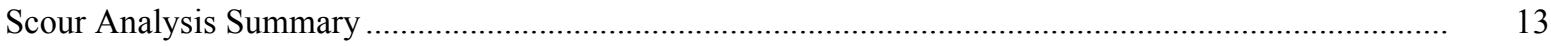

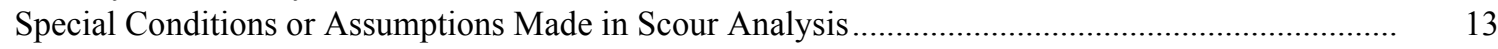

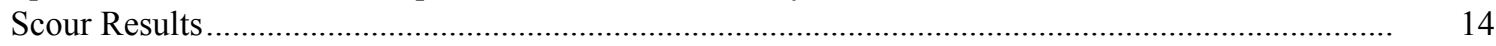

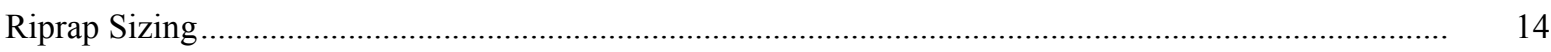

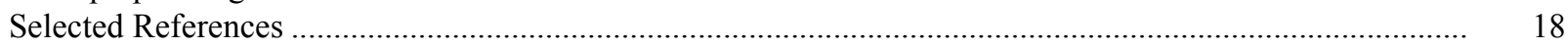

Appendices:

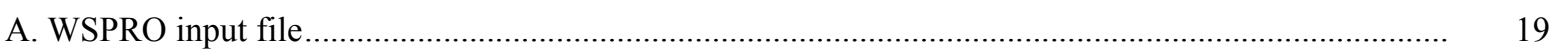

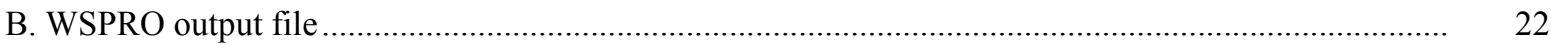

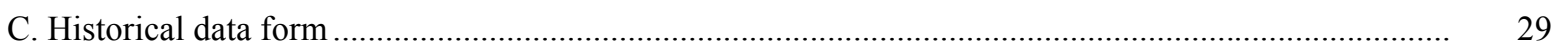

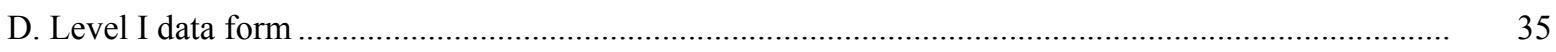

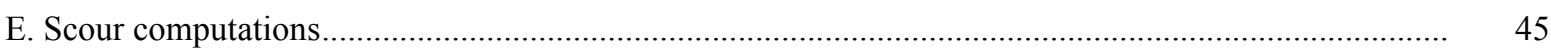

\section{FIGURES}

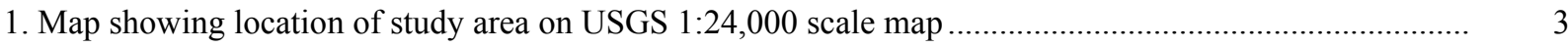

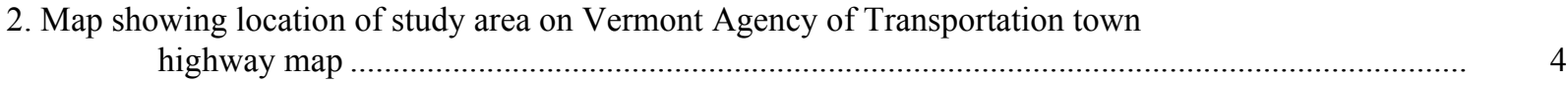

3. Structure SALITH00010008 viewed from upstream (June 12, 1996) ............................................... 5

4. Downstream channel viewed from structure SALITH00010008 (June 12, 1996)................................ 5

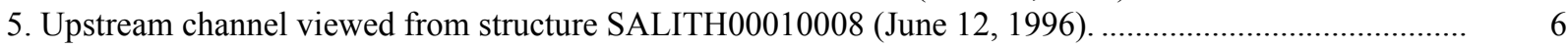

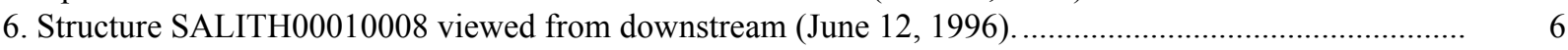

7. Water-surface profiles for the 100- and 500-year discharges at structure

SALITH00010008 on Town Highway 1, crossing Otter Creek,

Salisbury, Vermont.

8. Scour elevations for the 100- and 500-year discharges at structure

SALITH00010008 on Town Highway 1, crossing Otter Creek,

Salisbury, Vermont.

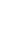
5

\section{TABLES}

1. Remaining footing/pile depth at abutments for the 100-year discharge at structure

SALITH00010008 on Town Highway 1, crossing Otter Creek,

Salisbury, Vermont

2. Remaining footing/pile depth at abutments for the 500-year discharge at structure

SALITH00010008 on Town Highway 1, crossing Otter Creek,

Salisbury, Vermont 


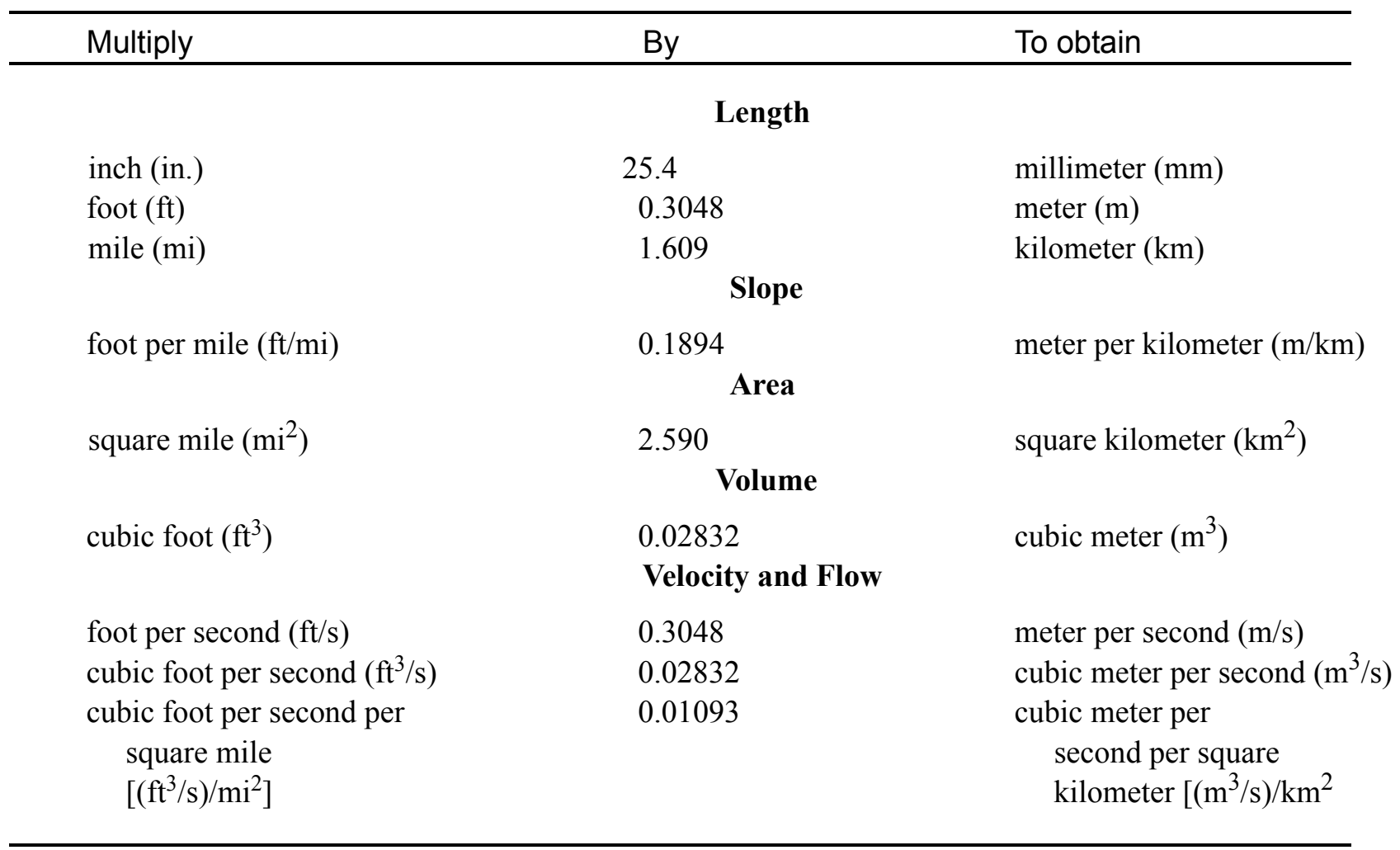

\section{OTHER ABBREVIATIONS}

$\begin{array}{lrlr}\mathrm{BF} & \text { bank full } & \text { LWW } & \text { left wingwall } \\ \mathrm{cfs} & \text { cubic feet per second } & \text { Max } & \text { maximum } \\ \mathrm{D}_{50} & \text { median diameter of bed material } & \text { MC } & \text { main channel } \\ \mathrm{DS} & \text { downstream } & \text { RAB } & \text { right abutment } \\ \mathrm{elev} & \text { elevation } & \text { RABUT } & \text { face of right abutment } \\ \mathrm{f} / \mathrm{p} & \text { flood plain } & \text { RB } & \text { right bank } \\ \mathrm{ft} & \text { square feet } & \text { ROB } & \text { right overbank } \\ \mathrm{ft} / \mathrm{ft} & \text { feet per foot } & \text { RWW } & \text { right wingwall } \\ \mathrm{FEMA} & \text { Federal Emergency Management Agency } & \text { TH } & \text { town highway } \\ \mathrm{FHWA} & \text { Federal Highway Administration } & \text { UB } & \text { under bridge } \\ \mathrm{JCT} & \text { junction } & \text { US } & \text { upstream } \\ \text { LAB } & \text { left abutment } & \text { USGS } & \text { United States Geological Survey } \\ \text { LABUT } & \text { face of left abutment } & \text { VTAOT } & \text { Vermont Agency of Transportation } \\ \text { LB } & \text { left bank } & \text { WSPRO } & \text { water-surface profile model } \\ \text { LOB } & \text { left overbank } & \text { yr } & \text { year }\end{array}$

In this report, the words "right" and "left" refer to directions that would be reported by an observer facing downstream. Sea level: In this report, "sea level" refers to the National Geodetic Vertical Datum of 1929-- a geodetic datum derived from a general adjustment of the first-order level nets of the United States and Canada, formerly called Sea Level Datum of 1929.

In the appendices, the above abbreviations may be combined. For example, USLB would represent upstream left bank. 


\title{
LEVEL II SCOUR ANALYSIS FOR BRIDGE 8 (SALITH00010008) ON TOWN HIGHWAY 1, CROSSING OTTER CREEK, SALISBURY, VERMONT
}

\author{
By Erick M. Boehmler and Laura Medalie
}

\section{INTRODUCTION AND SUMMARY OF RESULTS}

This report provides the results of a detailed Level II analysis of scour potential at structure SALITH00010008 on Town Highway 1 crossing Otter Creek, Salisbury, Vermont (figures 1-8). A Level II study is a basic engineering analysis of the site, including a quantitative analysis of stream stability and scour (FHWA, 1993). Results of a Level I scour investigation also are included in appendix $\mathrm{E}$ of this report. A Level I investigation provides a qualitative geomorphic characterization of the study site. Information on the bridge, gleaned from Vermont Agency of Transportation (VTAOT) files, was compiled prior to conducting Level I and Level II analyses and is found in appendix C.

The site is in the Champlain section of the St. Lawrence Valley physiographic province in west-central Vermont. The $543-\mathrm{mi}^{2}$ drainage area is in a predominantly rural and forested basin. In the vicinity of the study site, the surface cover is pasture except for the upstream left overbank area where the surface cover is predominantly wetland. Approximately 800 feet left of the site, the surface cover upstream and downstream becomes forested wetland (Cedar Swamp).

In the study area, Otter Creek has a straight channel with a slope of approximately 0.0004 $\mathrm{ft} / \mathrm{ft}$, an average channel top width of $118 \mathrm{ft}$ and an average bank height of $4 \mathrm{ft}$. The channel bed material ranges from organics to sand. Sieve analysis indicates that greater than $50 \%$ of the sample is silt and clay and thus a median grain size by use of sieve analysis was indeterminate. Therefore, the median grain was assumed to be medium silt with a size $\left(\mathrm{D}_{50}\right)$ of $0.0310 \mathrm{~mm}(0.000102 \mathrm{ft})$. The geomorphic assessment at the time of the Level I and Level II site visit on June 12, 1996, indicated that the reach was stable.

The Town Highway 1 crossing of Otter Creek is a 156-ft-long, one-lane bridge consisting of two 71-foot wooden thru-truss spans (Vermont Agency of Transportation, written communication, December 15, 1995). The opening length of the structure parallel to the bridge face is $133 \mathrm{ft}$. The bridge is supported by vertical abutments and one pier. The left abutment and the pier are concrete, and the right abutment is a mortared stone-block wall. The channel is skewed approximately 20 degrees to the opening while the computed opening-skew-to-roadway is 5 degrees. 
The only scour protection measure at the site was type- 1 stone fill (less than 12 inches diameter) on the left bank under the bridge in two isolated piles. Additional details describing conditions at the site are included in the Level II Summary and appendices C and D.

Scour depths and recommended rock rip-rap sizes were computed using the general guidelines described in Hydraulic Engineering Circular 18 (Richardson and Davis, 1995) for the 100- and 500-year discharges. In addition, the incipient roadway-overtopping discharge was determined and analyzed as another potential worst-case scour scenario. Total scour at a highway crossing is comprised of three components: 1) long-term streambed degradation; 2) contraction scour (due to accelerated flow caused by a reduction in flow area at a bridge) and; 3 ) local scour (caused by accelerated flow around piers and abutments). Total scour is the sum of the three components. Equations are available to compute depths for contraction and local scour and a summary of the results of these computations follows.

Contraction scour for all modelled flows ranged from 0.0 to $8.8 \mathrm{ft}$. The worst-case contraction scour occurred at the incipient roadway-overtopping discharge. Abutment scour ranged from 1.9 to $5.1 \mathrm{ft}$. The worst-case abutment scour occurred at the 500-year discharge. Additional information on scour depths and depths to armoring are included in the section titled "Scour Results". Scoured-streambed elevations, based on the calculated scour depths, are presented in tables 1 and 2. A cross-section of the scour computed at the bridge is presented in figure 8 . Scour depths were calculated assuming an infinite depth of erosive material and a homogeneous particle-size distribution.

Usually, computed scour depths are evaluated in combination with other information including (but not limited to) historical performance during flood events, the geomorphic stability assessment, existing scour protection measures, and the results of the hydraulic analyses. Therefore, scour depths adopted by VTAOT may differ from the computed values documented herein. 


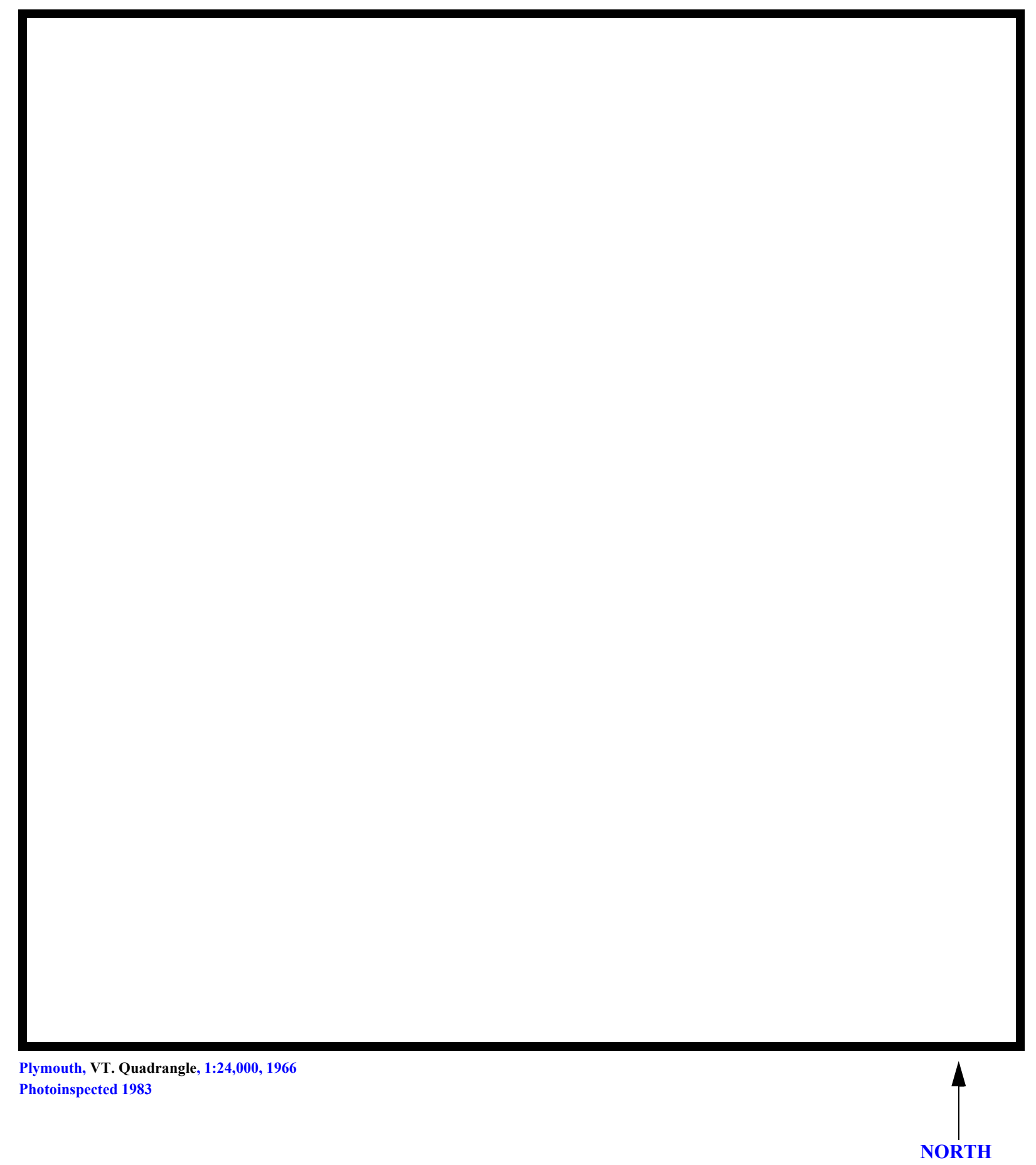

Figure 1. Location of study area on USGS 1:24,000 scale map. 
Figure 2. Location of study area on Vermont Agency of Transportation town highway map. 

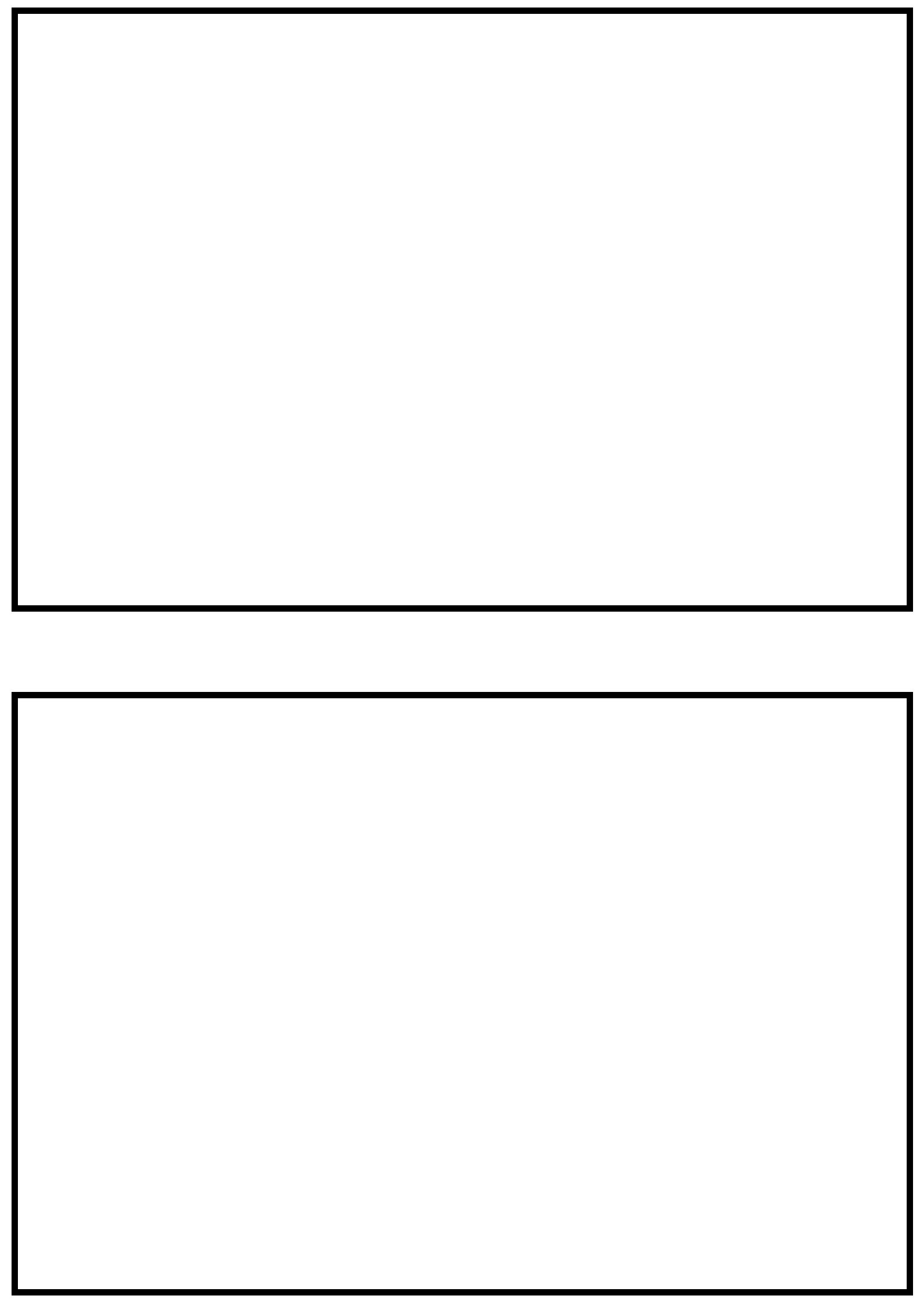

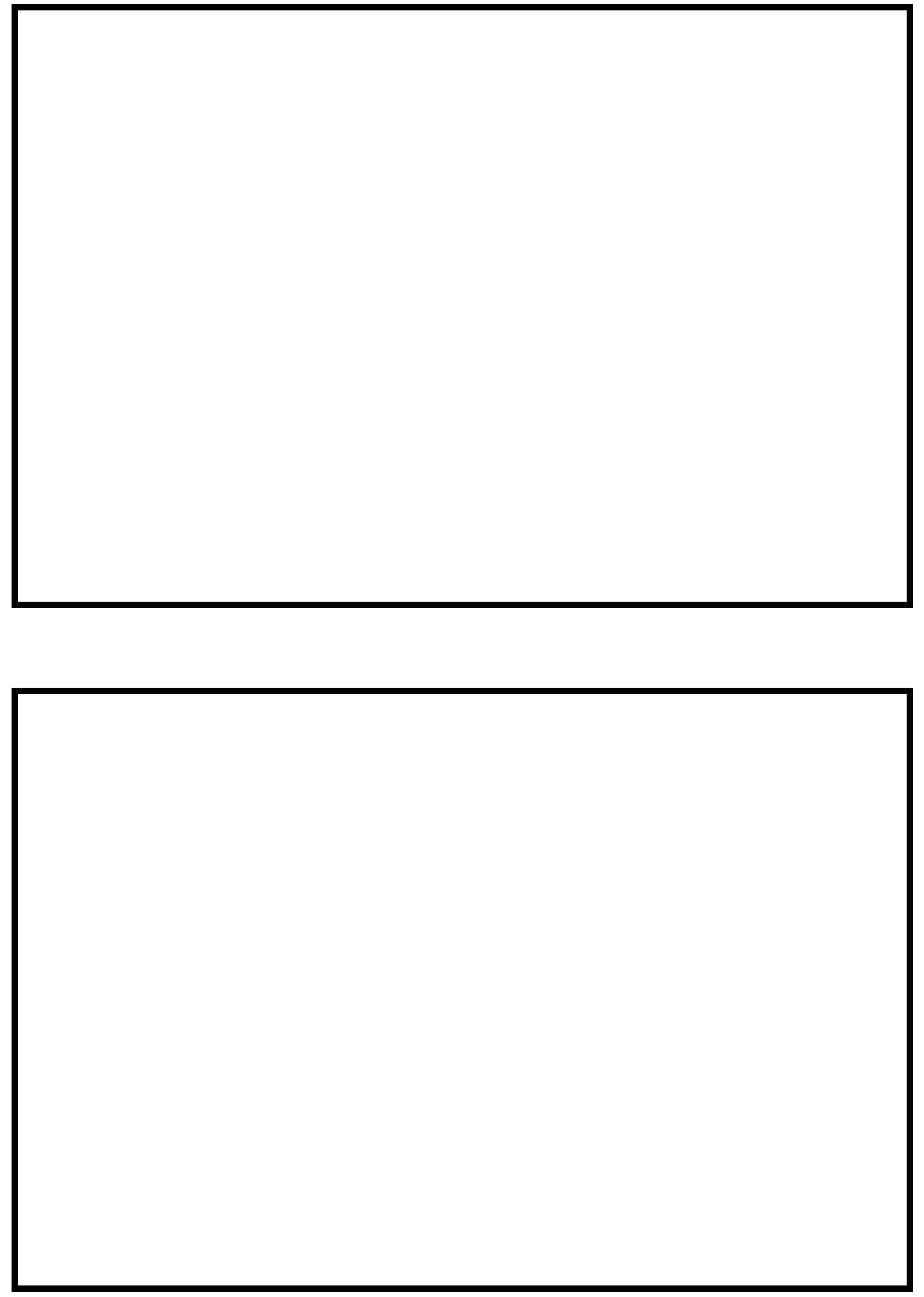


\section{LEVEL II SUMMARY}

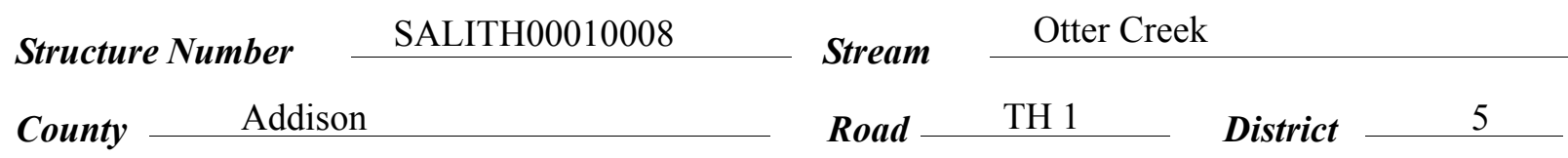

\section{Description of Bridge}

Bridge length $\frac{156}{f t}$ Bridge width $\frac{13.0}{f t}$ Max span length $\stackrel{71}{ }$ ft Alignment of bridge to road (on curve or straight) Abutment type Vertical

Stone fill on abutment? Yes Embankment type Straight

Dammintine af atam a fill Mato af insnortion Sloping $6 / 12 / 96$ isolated piles.

The right abutment is a stone wall with a concrete cap.

The left abutment is concrete. The pier is concrete with a sharp upstream end.

Yes

Is bridge skewed to flood flow according to No ' survey? Angle

Debris accumulation on bridge at time of Level I or Level II site visit:

\begin{tabular}{|c|c|c|c|}
\hline & $\begin{array}{c}\text { Date of insnortion } \\
6 / 12 / 96 \\
\end{array}$ & $\begin{array}{l}\text { Percent of ahmmal } \\
\text { blocked inotzontatly }\end{array}$ & $\begin{array}{l}\text { Percent of } 25 \\
\text { blocked verticatty }\end{array}$ \\
\hline & $6 / 12 / 96$ & -- & -- \\
\hline
\end{tabular}

Level II

High. The channel flows through a forested swamp upstream.

Debris was observed at the upstream bridge face.

Potential for debris

None were observed on 6/12/96.

Doscriho anv, foaturos noar ar at tho hridos that mav' affoct flow, (includo ahsorvation dato) 


\section{Description of the Geomorphic Setting}

General topography The channel is located in a low relief valley setting with a wide flood plain and moderately sloped valley walls on both sides.

Geomorphic conditions at bridge site: downstream (DS), upstream (US)

Date of inspection $\quad 6 / 12 / 96$

DS left: $\quad$ Steep channel bank to an irregular flood plain

DS right: $\quad$ Steep channel bank to an irregular overbank

US left: $\quad$ Moderately sloped channel bank to an irregular flood plain

US right: $\quad$ Moderately sloped channel bank to an irregular overbank

\section{Description of the Channel}

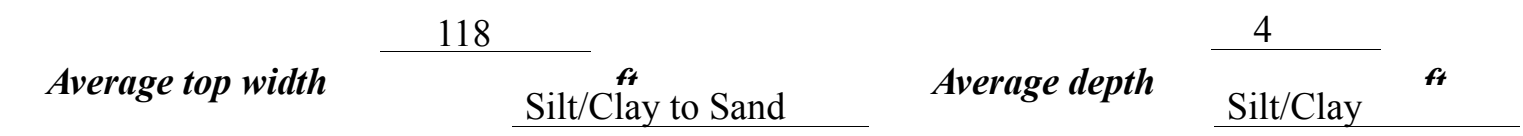

Predominant bed material

Bank material

Perennial and straight

with a constant width and alluvial channel boundaries.

$6 / 12 / 96$

Vegetative co 1 Trees with shrubs and brush.

DS left: $\quad$ Shrubs and brush with a few trees.

DS right: $\quad$ Trees with shrubs and brush.

US left: $\quad$ Shrubs and brush with a few trees.

US right: $\quad$ Yes

Do banks appear stable? -

y mug, пе

date of observatton.

A large mass of debris

(whole trees) across the entire channel width at the upstream face of the bridge, was observed Describe any obstructions in channel and date of observation.

lodged on the pier on 6/12/96. 


\section{Hydrology}

Drainage area $\stackrel{543}{\mathrm{mi}} \mathbf{i}^{2}$

Percentage of drainage area in physiographic provinces: (approximate)

Physiographic province/section

St. Lawrence Valley / Champlain

New England / Taconic
Percent of drainage area 40

60

Is drainage area considered rural or urban?

Rural None.

urbanization:

Yes

Is there a USGS gage on the stream of interest?

Otter Creek at Middlebury, VT

USGS gage description

04282500

USGS gage number 628

Gage drainage area

Gage drainage area

$m i^{2}$

No

Is there a lake' -

-

\section{Describe any significant}




\section{Description of the Water-Surface Profile Model (WSPRO) Analysis}

Datum for WSPRO analysis (USGS survey, sea level, VTAOT plans)

USGS survey

Datum tie between USGS survey and VTAOT plans

None

Description of reference marks used to determine USGS datum. $\quad$ RM1 is a chiseled " $X$ "

on the right abutment concrete at the upstream end at the corner nearest the bank (elev. $500.15 \mathrm{ft}$,

arbitrary survey datum). RM2 is a chiseled " $\mathrm{X}$ " on a boulder at the downstream end of the left

abutment nearest the bank (elev. $503.76 \mathrm{ft}$, arbitrary survey datum).

\section{Cross-Sections Used in WSPRO Analysis}

\begin{tabular}{cccl}
\hline${ }^{1}$ Cross-section & $\begin{array}{c}\text { Section } \\
\text { Reference } \\
\text { Distance } \\
(\text { SRD) } \text { in feet }\end{array}$ & $\begin{array}{c}{ }^{2} \text { Cross-section } \\
\text { development }\end{array}$ & \multicolumn{1}{c}{ Comments } \\
\hline EXITX & -140 & 1 & Exit section \\
FULLV & 0 & 2 & $\begin{array}{l}\text { Downstream Full-valley } \\
\text { section (Templated from } \\
\text { EXITX) }\end{array}$ \\
BRIDG & 0 & 1 & Bridge section \\
RDWAY & 8 & 1 & Road Grade section \\
APPRO & 148 & 1 & Approach section \\
\hline
\end{tabular}

${ }^{1}$ For location of cross-sections see plan-view sketch included with Level I field form, appendix E.

For more detail on how cross-sections were developed see WSPRO input file. 


\section{Data and Assumptions Used in WSPRO Model}

Hydraulic analyses of the reach were done by use of the Federal Highway Administration's WSPRO step-backwater computer program (Shearman and others, 1986, and Shearman, 1990). The analyses reported herein reflect conditions existing at the site at the time of the study. Furthermore, in the development of the model it was necessary to assume no accumulation of debris or ice at the site. For each discharge modeled, flow through the bridge was assumed to align with the abutment walls. Flow through several culverts was assumed negligible for the discharges modeled. Results of the hydraulic model are presented in the Bridge Hydraulic Summary, appendix B, and figure 7.

Channel roughness factors (Manning's "n”) used in the hydraulic model were estimated using field inspections at each cross section following the general guidelines described by Arcement and Schneider (1989). Final adjustments to the values were made during the modelling of the reach. Channel " $n$ " values for the reach ranged from 0.035 to 0.040 , and overbank " $n$ " values ranged from 0.040 to 0.070 .

Normal depth at the exit section (EXITX) was assumed as the starting water surface. This depth was computed by use of the slope-conveyance method outlined in the user's manual for WSPRO (Shearman, 1990). The slope used was $0.00032 \mathrm{ft} / \mathrm{ft}$, which was estimated from records for the gage at Middlebury and topographic map contour lines (U.S. Geological Survey, 1943).

The surveyed approach section was moved with no elevation correction to establish the modelled approach section (APPRO), one bridge length upstream of the upstream face as recommended by Shearman and others (1986). This location provides a consistent method for determining scour variables. 


\section{Bridge Hydraulics Summary}

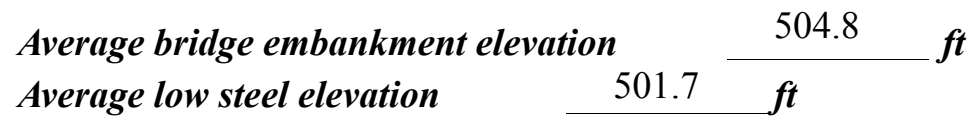

100-year discharge $\quad 10,200 \quad \mathrm{ft}^{3} / \mathrm{s}$

Water-surface elevation in bridge opening $\quad 499.0 \quad f t$

Road overtopping? ___ Yes Discharge over road _ $\quad \begin{array}{lll}6,810 & \mathrm{ft}^{3} / \mathrm{s}\end{array}$

Area of flow in bridge opening $\quad 1,430 \quad \mathrm{ft}^{2}$

Average velocity in bridge opening $\quad 2.4 \quad \mathrm{ft} / \mathrm{s}$

$\begin{array}{lll}\text { Maximum WSPRO tube velocity at bridge } & 2.9 & \mathrm{ft} / \mathrm{s}\end{array}$

Water-surface elevation at Approach section with bridge 499.3

Water-surface elevation at Approach section without bridge $\quad 499.0$

Amount of backwater caused by bridge $\quad 0.3$ it

500-year discharge $\quad 13,200 \quad \mathrm{ft}^{3} / \mathrm{s}$

Water-surface elevation in bridge opening $499.6 \mathrm{ft}$

Road overtopping? ___ Yes Discharge over road _ $12,300 \mathrm{ft}^{3} / \mathbf{s}$

Area of flow in bridge opening $\quad 1,510 \quad \mathrm{ft}^{2}$

Average velocity in bridge opening $0.6 \mathrm{ft} / \mathrm{s}$

Maximum WSPRO tube velocity at bridge $\quad 0.8$ 's

Water-surface elevation at Approach section with bridge 499.6

Water-surface elevation at Approach section without bridge $\quad 499.5$

Amount of backwater caused by bridge $\quad 0.1, t$

Incipient overtopping discharge $\quad 6,730 \quad \mathrm{ft}^{3} / \mathrm{s}$

Water-surface elevation in bridge opening 497.6 t

Area of flow in bridge opening $\quad 1,240 \quad \mathrm{ft}^{2}$

Average velocity in bridge opening $\quad 5.4 \quad \mathrm{ft} / \mathrm{s}$

Maximum WSPRO tube velocity at bridge $\quad 6.6 \mathrm{ft} / \mathrm{s}$

Water-surface elevation at Approach section with bridge

Water-surface elevation at Approach section without bridge

Amount of backwater caused by bridge $\quad 0.6$ it

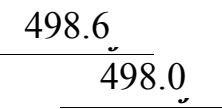




\section{Scour Analysis Summary}

\section{Special Conditions or Assumptions Made in Scour Analysis}

Scour depths were computed using the general guidelines described in Hydraulic Engineering Circular 18 (Richardson and Davis, 1995). Scour depths were calculated assuming an infinite depth of erosive material and a homogeneous particle-size distribution. The results of the scour analyses for the 100- and 500-year discharges are presented in tables 1 and 2 and the scour depths are shown graphically in figure 8.

Contraction scour for each modeled discharge was computed by use of the Laursen live-bed contraction scour equation (Richardson and Davis, 1995, p. 30, equation 17). Variables for the live-bed contraction scour equation include the bottom width, depth, and discharge in the bridge opening and in the approach main channel, the shear velocity in the approach channel, and the fall velocity of the median sized particle of the bed material.

Pier scour was computed by use of a modified equation developed at Colorado State University (Richardson and others, 1995, p. 36, equation 21) for all discharges modeled. Variables for the pier scour equation include pier length, pier width, average depth and maximum velocity (for the Froude number) immediately upstream of the bridge, and four correction factors for pier shape, flow attack angle, streambed-form, and streambed armoring.

Abutment scour was computed by use of the HIRE equation (Richardson and Davis, 1995, p. 49, equation 29) because the HIRE equation is recommended when the length to depth ratio of the embankment blocking flow exceeds 25 . Variables for the HIRE equation include the Froude number of the flow approaching the embankments, the length of the embankment blocking flow, and the depth of flow approaching the embankment less any roadway overtopping. 


\section{Scour Results}

Contraction scour:

$\begin{array}{rrr}\text { 100-year } & \text { Incipient } \\ \text { discharge } & \text { discharge } & \text { overtopping } \\ \text { discharge }\end{array}$

(Scour depths in feet)

Main channel

Live-bed scour

0.0

Clear-water scour

Depth to armoring

Left overbank

Right overbank

Local scour:

Abutment scour

Left abutment

4.7

5.1

3.8

$3.5-$

$5.0-$

1.9-

Right abutment

Pier scour

10.4

5.9

14.7

Pier 1
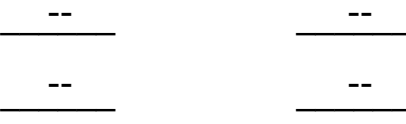

Pier 2

Pier 3

\section{Riprap Sizing}

Abutments:

Left abutment

100-year

discharge

Right abutment

Piers:

Pier 1

Pier 2
0.3

0.3

$0.2-$

$--$

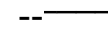

Incipient

500-year discharge ( $D_{50}$ in feet) 0.0

0.0

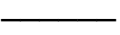

$0.0^{-}$

$0.9^{-}$

overtopping discharge

1.1

1.1
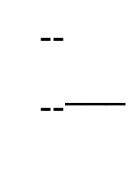


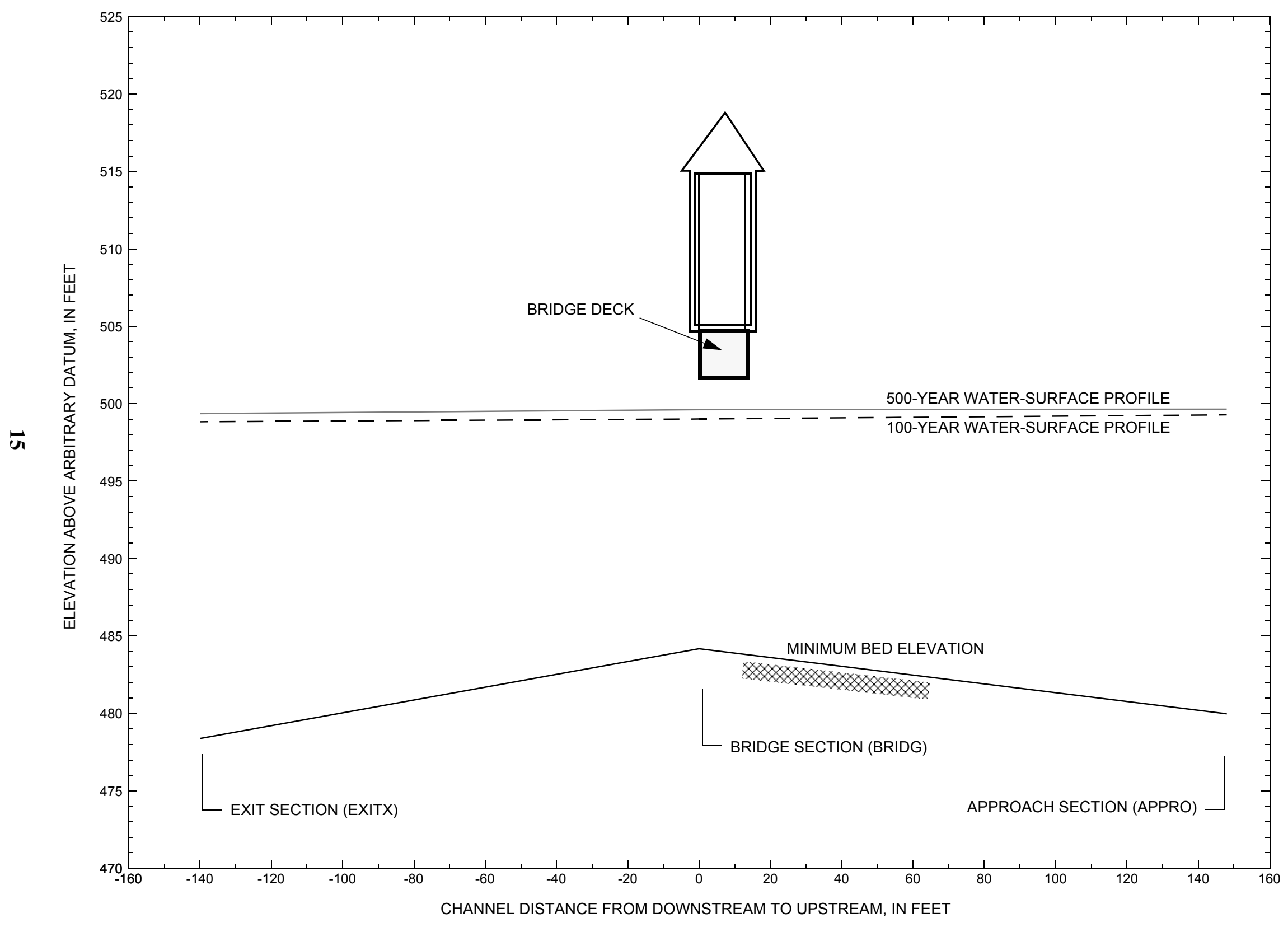

Figure 7. Water-surface profiles for the 100- and 500-year discharges at structure SALITH00010008 on Town Highway 1, crossing Otter Creek, Salisbury, Vermont. 


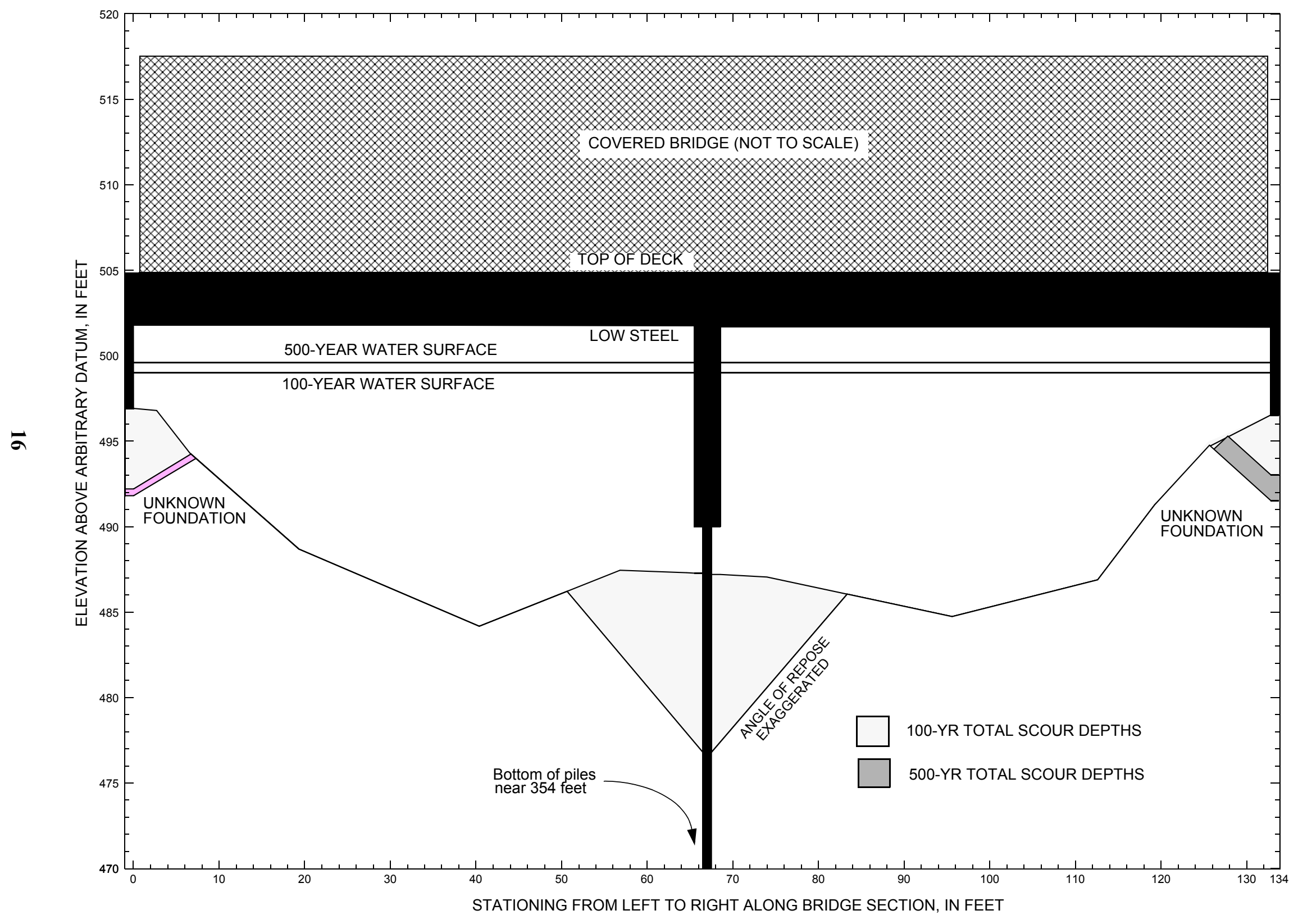

Figure 8. Scour elevations for the 100- and 500-year discharges at structure SALITH00010008 on Town Highway 1, crossing Otter Creek, Salisbury, Vermont. 


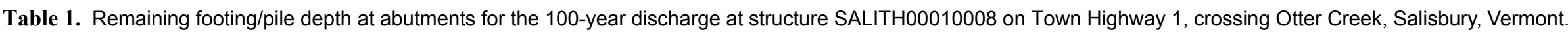
[VTAOT, Vermont Agency of Transportation; --, no data]

\begin{tabular}{|c|c|c|c|c|c|c|c|c|c|c|c|}
\hline Description & Station $^{1}$ & $\begin{array}{c}\text { VTAOT } \\
\text { minimum } \\
\text { low-chord } \\
\text { elevation } \\
\text { (feet) }\end{array}$ & $\begin{array}{c}\text { Surveyed } \\
\text { minimum } \\
\text { low-chord } \\
\text { elevation } \\
\text { (feet) }\end{array}$ & $\begin{array}{c}\text { Bottom of } \\
\text { footing/pile } \\
\text { elevation } \\
\text { (feet) }\end{array}$ & $\begin{array}{c}\text { Channel } \\
\text { elevation at } \\
\text { abutment/ } \\
\text { pier }^{2} \\
\text { (feet) }\end{array}$ & $\begin{array}{c}\text { Contraction } \\
\text { scour depth } \\
\text { (feet) }\end{array}$ & $\begin{array}{l}\text { Abutment } \\
\text { scour } \\
\text { depth } \\
\text { (feet) }\end{array}$ & $\begin{array}{l}\text { Pier } \\
\text { scour } \\
\text { depth } \\
\text { (feet) }\end{array}$ & $\begin{array}{l}\text { Depth of } \\
\text { total scour } \\
\text { (feet) }\end{array}$ & $\begin{array}{c}\text { Elevation of } \\
\text { scour }^{2} \\
\text { (feet) }\end{array}$ & $\begin{array}{c}\text { Remaining } \\
\text { footing/pile } \\
\text { depth } \\
\text { (feet) }\end{array}$ \\
\hline \multicolumn{12}{|c|}{100 -year discharge is 10,200 cubic-feet per second } \\
\hline Left abutment & 0.0 & -- & 501.8 & -- & 496.9 & 0.0 & 4.7 & -- & 4.7 & 492.2 & -- \\
\hline Pier & 67.0 & -- & 500.0 & 354. & 487.2 & 0.0 & -- & 10.4 & -- & 476.8 & $\sim 344$. \\
\hline Right abutment & 132.8 & -- & 501.6 & -- & 496.5 & 0.0 & 3.5 & -- & 3.5 & 493.0 & -- \\
\hline
\end{tabular}

1.Measured along the face of the most constricting side of the bridge.

2.Arbitrary datum for this study.

Table 2. Remaining footing/pile depth at abutments for the 500-year discharge at structure SALITH00010008 on Town Highway 1, crossing Otter Creek, Salisbury, Vermont. [VTAOT, Vermont Agency of Transportation; --, no data]

\begin{tabular}{|c|c|c|c|c|c|c|c|c|c|c|c|}
\hline Description & Station $^{1}$ & $\begin{array}{l}\text { VTAOT } \\
\text { minimum } \\
\text { low-chord } \\
\text { elevation } \\
\text { (feet) }\end{array}$ & $\begin{array}{l}\text { Surveyed } \\
\text { minimum } \\
\text { low-chord } \\
\text { elevation }{ }^{2} \\
\text { (feet) }\end{array}$ & $\begin{array}{c}\text { Bottom of } \\
\text { footing/pile } \\
\text { elevation }{ }^{2} \\
\text { (feet) }\end{array}$ & $\begin{array}{c}\text { Channel } \\
\text { elevation at } \\
\text { abutment/ } \\
\text { pier }^{2} \\
\text { (feet) }\end{array}$ & $\begin{array}{l}\text { Contraction } \\
\text { scour depth } \\
\text { (feet) }\end{array}$ & $\begin{array}{l}\text { Abutment } \\
\text { scour } \\
\text { depth } \\
\text { (feet) }\end{array}$ & $\begin{array}{l}\text { Pier } \\
\text { scour } \\
\text { depth } \\
\text { (feet) }\end{array}$ & $\begin{array}{l}\text { Depth of } \\
\text { total scour } \\
\text { (feet) }\end{array}$ & $\begin{array}{c}\text { Elevation of } \\
\text { scour }^{2} \\
\text { (feet) }\end{array}$ & $\begin{array}{c}\text { Remaining } \\
\text { footing/pile } \\
\text { depth } \\
\text { (feet) }\end{array}$ \\
\hline \multicolumn{12}{|c|}{500 -year discharge is 13,200 cubic-feet per second } \\
\hline Left abutment & 0.0 & -- & 501.8 & -- & 496.9 & 0.0 & 5.1 & -- & 5.1 & 491.8 & -- \\
\hline Pier & 67.0 & -- & 500.0 & 354. & 487.2 & 0.0 & -- & 5.9 & 5.9 & 481.3 & $\sim 348$ \\
\hline Right abutment & 132.8 & -- & 501.6 & -- & 496.5 & 0.0 & 5.0 & -- & 5.0 & 491.5 & -- \\
\hline
\end{tabular}

1.Measured along the face of the most constricting side of the bridge.

2.Arbitrary datum for this study. 


\section{SELECTED REFERENCES}

Arcement, G.J., Jr., and Schneider, V.R., 1989, Guide for selecting Manning's roughness coefficients for natural channels and flood plains: U.S. Geological Survey Water-Supply Paper 2339, 38 p.

Barnes, H.H., Jr., 1967, Roughness characteristics of natural channels: U.S. Geological Survey Water-Supply Paper 1849,213 p.

Benson, M. A., 1962, Factors Influencing the Occurrence of Floods in a Humid Region of Diverse Terrain: U.S. Geological Survey WaterSupply Paper 1580-B, 64 p.

Brown, S.A. and Clyde, E.S., 1989, Design of riprap revetment: Federal Highway Administration Hydraulic Engineering Circular No. 11, Publication FHWA-IP-89-016, 156 p.

Federal Highway Administration, 1983, Runoff estimates for small watersheds and development of sound design: Federal Highway Administration Report FHWA-RD-77-158.

Federal Highway Administration, 1993, Stream Stability and Scour at Highway Bridges: Participant Workbook: Federal Highway Administration Report FHWA-HI-91-011.

Froehlich, D.C., 1989, Local scour at bridge abutments in Ports, M.A., ed., Hydraulic Engineering--Proceedings of the 1989 National Conference on Hydraulic Engineering: New York, American Society of Civil Engineers, p. 13-18.

Hayes, D.C.,1993, Site selection and collection of bridge-scour data in Delaware, Maryland, and Virginia: U.S. Geological Survey WaterResources Investigation Report 93-4017, 23 p.

Interagency Advisory Committee on Water Data, 1982, Guidelines for determining flood flow frequency: U.S. Geological Survey, Bulletin 17B of the Hydrology Subcommittee, 190 p.

Johnson, C.G. and Tasker, G.D.,1974, Progress report on flood magnitude and frequency of Vermont streams: U.S. Geological Survey OpenFile Report 74-130, 37 p.

Lagasse, P.F., Schall, J.D., Johnson, F., Richardson, E.V., Chang, F., 1995, Stream Stability at Highway Structures: Federal Highway Administration Hydraulic Engineering Circular No. 20, Publication FHWA-IP-90-014, 144 p.

Laursen, E.M., 1960, Scour at bridge crossings: Journal of the Hydraulics Division, American Society of Civil Engineers, v. 86, no. HY2, p. 39-53.

Potter, W. D., 1957a, Peak rates of runoff in the Adirondack, White Mountains, and Maine woods area, Bureau of Public Roads

Potter, W. D., 1957b, Peak rates of runoff in the New England Hill and Lowland area, Bureau of Public Roads

Richardson, E.V. and Davis, S.R., 1995, Evaluating scour at bridges: Federal Highway Administration Hydraulic Engineering Circular No. 18, Publication FHWA-IP-90-017, 204 p.

Richardson, E.V., Simons, D.B., and Julien, P.Y., 1990, Highways in the river environment: Federal Highway Administration Publication FHWA-HI-90-016.

Ritter, D.F., 1984, Process Geomorphology: W.C. Brown Co., Debuque, Iowa, 603 p.

Shearman, J.O., 1990, User's manual for WSPRO--a computer model for water surface profile computations: Federal Highway Administration Publication FHWA-IP-89-027, 187 p.

Shearman, J.O., Kirby, W.H., Schneider, V.R., and Flippo, H.N., 1986, Bridge waterways analysis model; research report: Federal Highway Administration Publication FHWA-RD-86-108, 112 p.

Talbot, A.N., 1887, The determination of water-way for bridges and culverts.

U.S. Geological Survey, 1943, Cornwall, Vermont 7.5 Minute Series quadrangle map: U.S. Geological Survey Topographic Maps, Photoinspected 1983, Contour Interval, 20 feet, Scale 1:24,000. 


\section{APPENDIX A: \\ WSPRO INPUT FILE}




\section{WSPRO INPUT FILE}

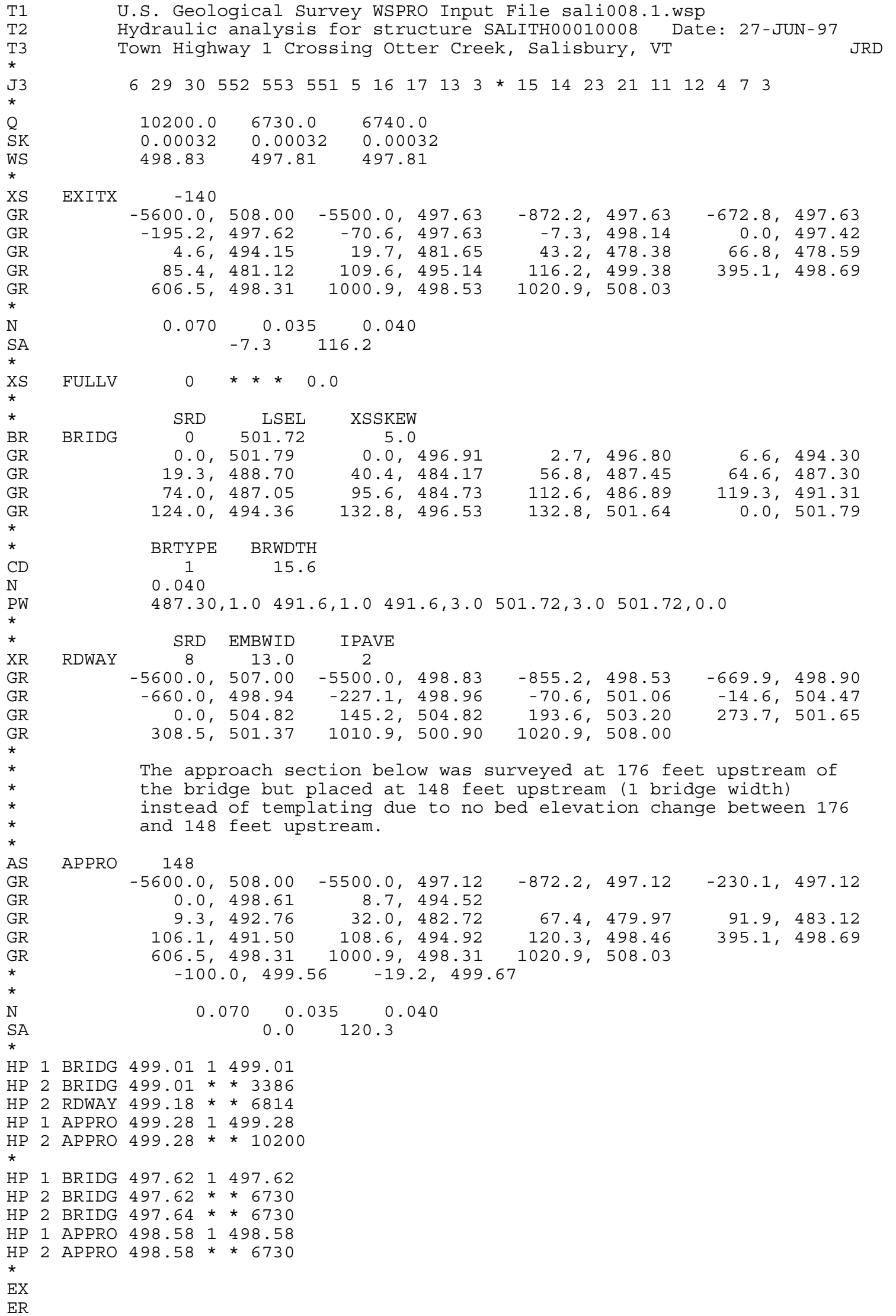




\section{WSPRO INPUT FILE (continued)}

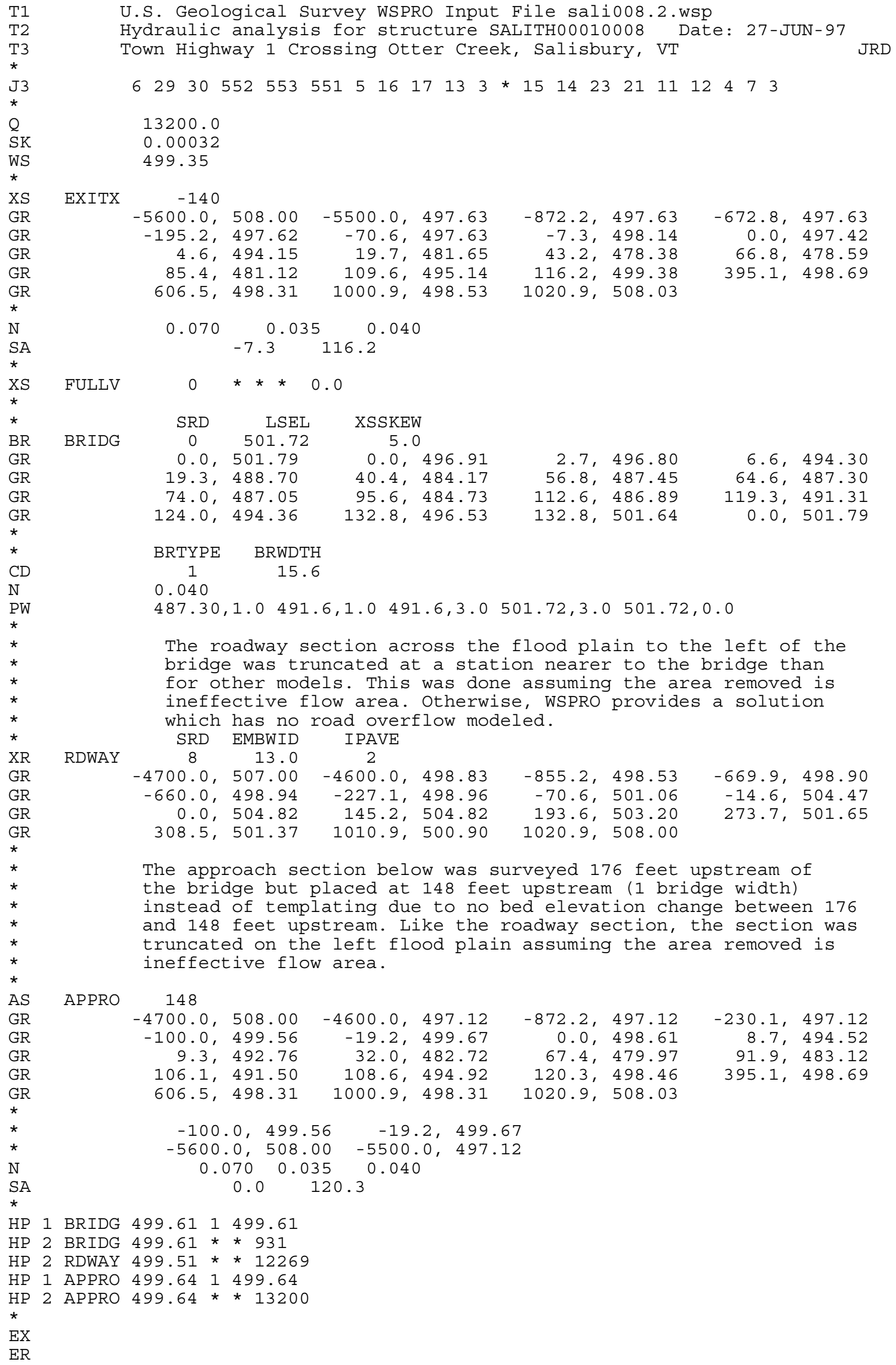




\section{APPENDIX B: \\ WSPRO OUTPUT FILE}


WSPRO OUTPUT FILE

WSPRO

FEDERAL HIGHWAY ADMINISTRATION - U. S. GEOLOGICAL SURVEY

MODEL FOR WATER-SURFACE PROFILE COMPUTATIONS

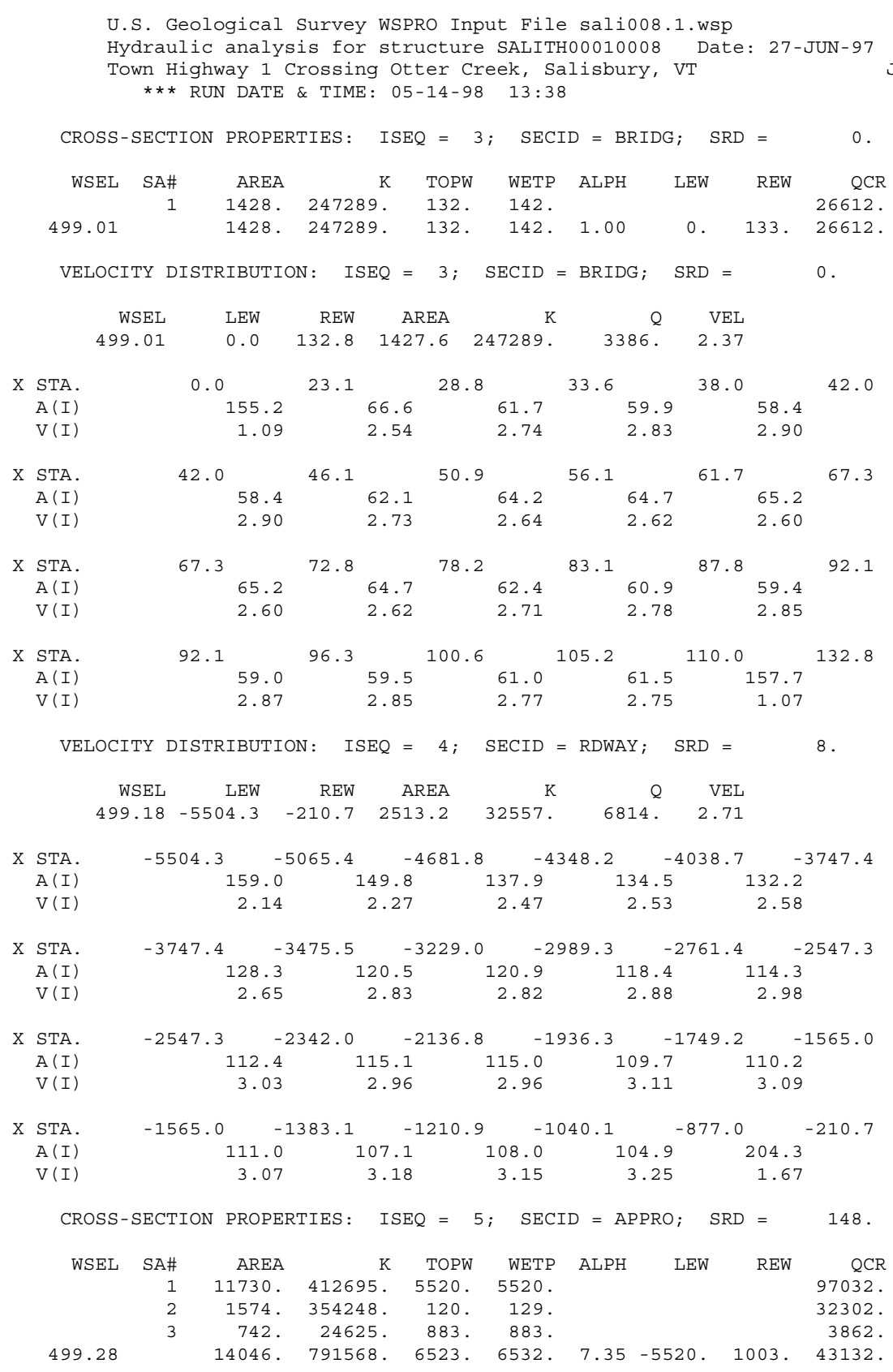

VELOCITY DISTRIBUTION: ISEQ $=5 ;$ SECID $=$ APPRO $; \quad \operatorname{SRD}=148$.

$\begin{array}{rrrrrrr}\text { WSEL } & \text { LEW } & \text { REW } & \text { AREA } & \text { K } & \text { Q } & \text { VEL } \\ 499.28 & -5519.9 & 1002.9 & 14046.0 & 791568 . & 10200 . & 0.73\end{array}$

\begin{tabular}{|c|c|c|c|c|c|c|c|}
\hline \multirow[t]{3}{*}{ X } & STA. & -5519.9 & -4994.2 & -4467.5 & -3952.1 & -3444.7 & -2924.0 \\
\hline & $A(I)$ & 1113.9 & 1137.8 & 1113.2 & 1095.9 & \multicolumn{2}{|c|}{1124.9} \\
\hline & $V(I)$ & 0.46 & 0.45 & 0.46 & 0.47 & \multicolumn{2}{|c|}{0.45} \\
\hline \multirow[t]{3}{*}{$\mathrm{X}$} & STA. & -2924.0 & -2410.1 & -1893.6 & 1385.3 & -864.8 & -344.3 \\
\hline & $A(I)$ & 1110.1 & 1115.5 & 1098.1 & 1124.2 & \multicolumn{2}{|c|}{1124.2} \\
\hline & $\mathrm{V}(\mathrm{I})$ & 0.46 & 0.46 & 0.46 & 0.45 & \multicolumn{2}{|c|}{0.45} \\
\hline \multirow[t]{3}{*}{$\mathrm{x}$} & STA. & -344.3 & 23.1 & 35.4 & 44.7 & 53.0 & 60.9 \\
\hline & $A(I)$ & 731.9 & 185.7 & 159.9 & 149.1 & \multicolumn{2}{|c|}{146.4} \\
\hline & $V(I)$ & 0.70 & 2.75 & 3.19 & 3.42 & \multicolumn{2}{|c|}{3.48} \\
\hline \multirow[t]{3}{*}{$\mathrm{x}$} & STA. & 60.9 & \multirow{2}{*}{$\begin{array}{r}68.2 \\
142.1\end{array}$} & 75.8 & 83.7 & 92.5 & 1002.9 \\
\hline & $A(I)$ & 138.4 & & \multirow{2}{*}{$\begin{array}{r}140.8 \\
3.62\end{array}$} & 145.5 & \multicolumn{2}{|c|}{948.6} \\
\hline & $V(I)$ & 3.69 & 3.59 & & 3.50 & & \\
\hline
\end{tabular}


WSPRO FEDERAL HIGHWAY ADMINISTRATION - U. S. GEOLOGICAL SURVEY

V060188 MODEL FOR WATER-SURFACE PROFILE COMPUTATIONS

U.S. Geological Survey WSPRO Input File sali008.1.wsp

Hydraulic analysis for structure SALITH00010008 Date: 27-JUN-97

Town Highway 1 Crossing Otter Creek, Salisbury, VT *** RUN DATE \& TIME: 06-25-98 16:14

CROSS-SECTION PROPERTIES: ISEQ $=3 ;$ SECID $=$ BRIDG $;$ SRD $=$

0 .

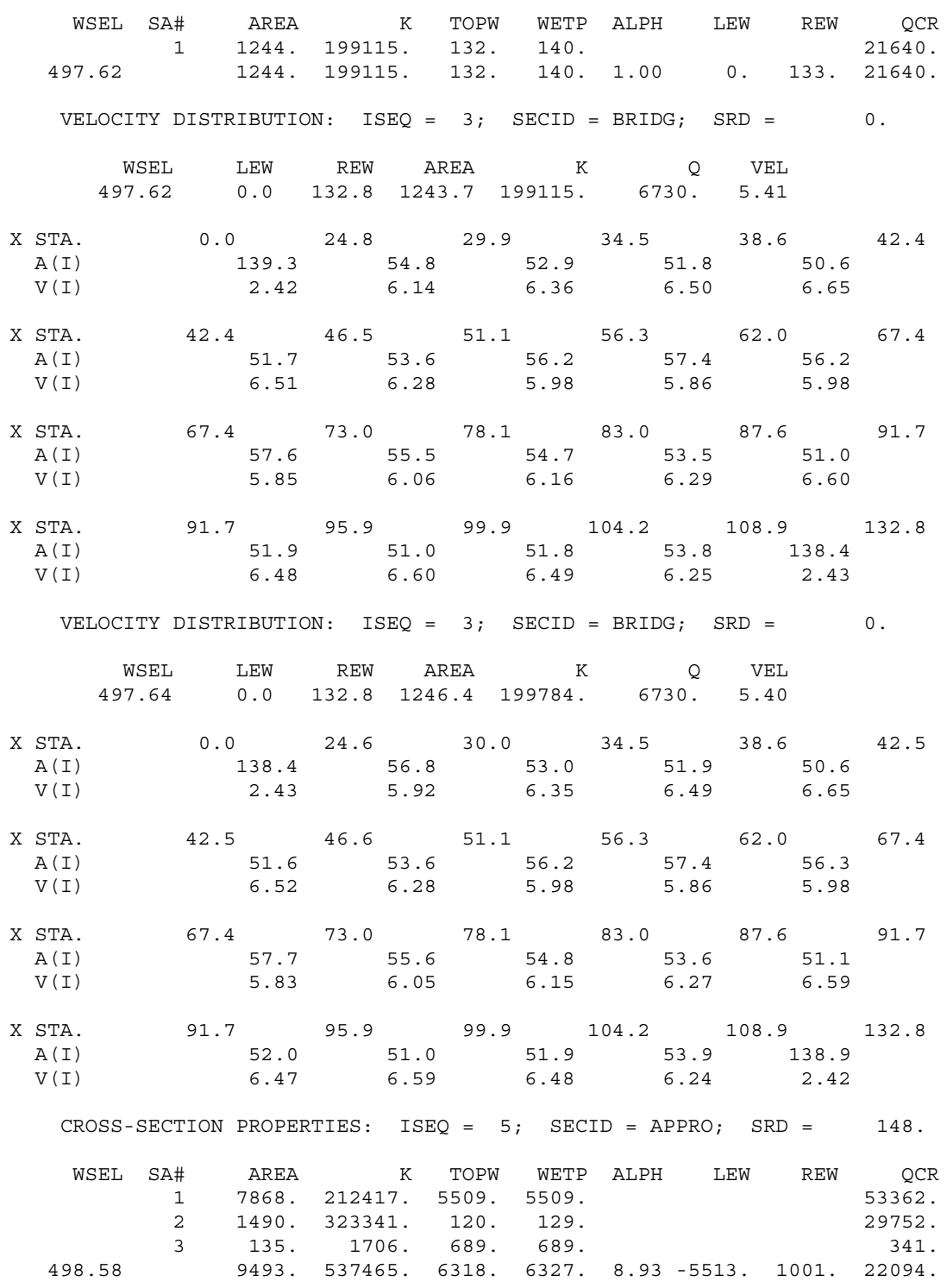

VELOCITY DISTRIBUTION: ISEQ $=5 ; \quad \operatorname{SECID}=$ APPRO $; \quad \operatorname{SRD}=148$.

$\begin{array}{rrrrrrr}\text { WSEL } & \text { LEW } & \text { REW } & \text { AREA } & \text { K } & \text { Q } & \text { VEL } \\ 498.58 & -5513.4 & 1001.5 & 9493.4 & 537465 . & 6730 . & 0.71\end{array}$

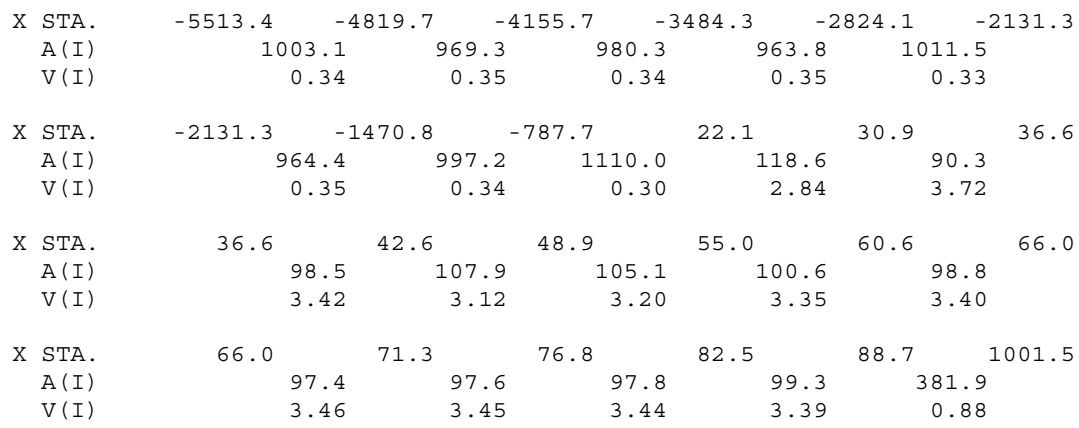


WSPRO FEDERAL HIGHWAY ADMINISTRATION - U. S. GEOLOGICAL SURVEY

V060188 MODEL FOR WATER-SURFACE PROFILE COMPUTATIONS

U.S. Geological Survey WSPRO Input File sali008.1.wsp

Hydraulic analysis for structure SALITH00010008 Date: 27-JUN-97

Town Highway 1 Crossing Otter Creek, Salisbury, VT *** RUN DATE \& TIME: 05-14-98 $13: 38$

CROSS-SECTION PROPERTIES: ISEQ $=3 ;$ SECID $=$ BRIDG $;$ SRD $=$

0 .

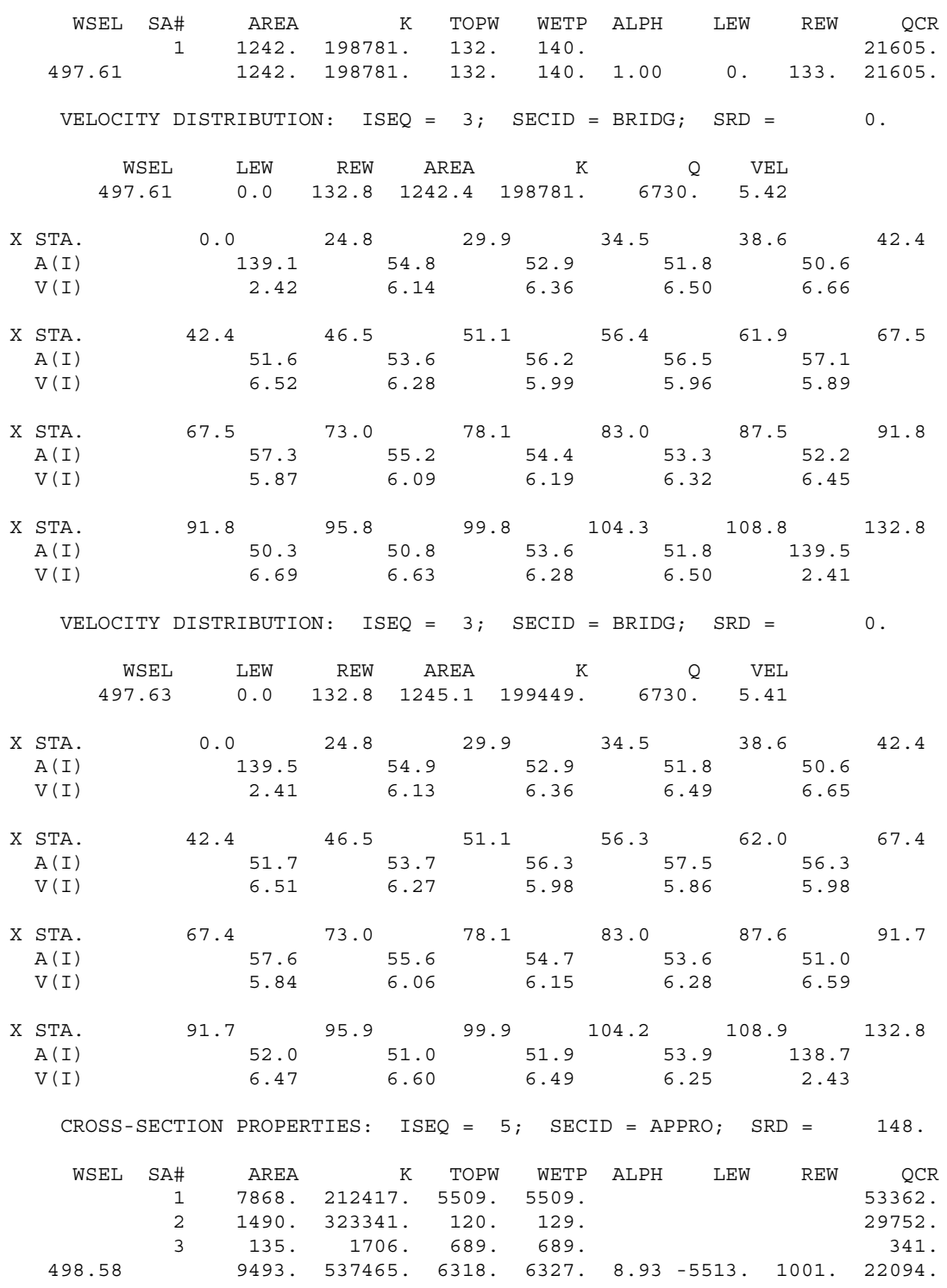

VELOCITY DISTRIBUTION: ISEQ $=5 ; \quad \operatorname{SECID}=$ APPRO $; \quad \operatorname{SRD}=148$.

$\begin{array}{rrrrrrr}\text { WSEL } & \text { LEW } & \text { REW } & \text { AREA } & \text { K } & \text { Q } & \text { VEL } \\ 498.58 & -5513.4 & 1001.5 & 9493.4 & 537465 . & 6730 . & 0.71\end{array}$

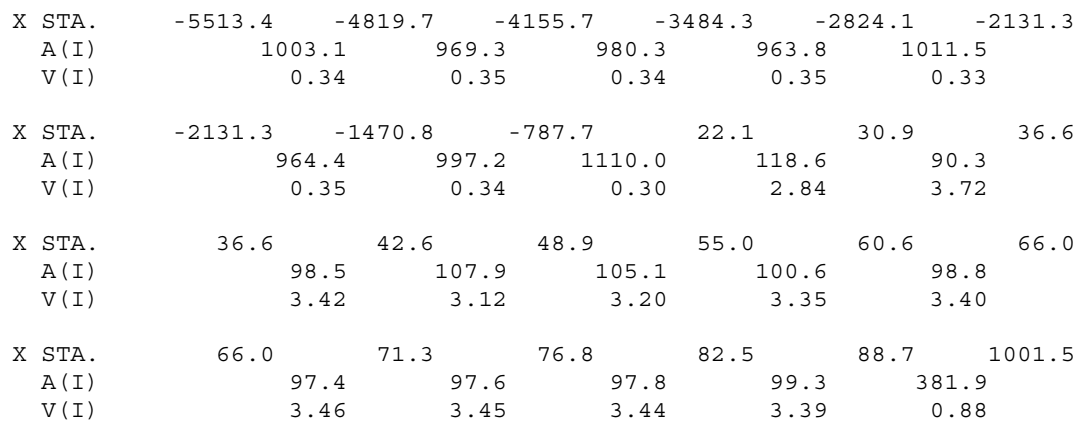


WSPRO OUTPUT FILE (continued)

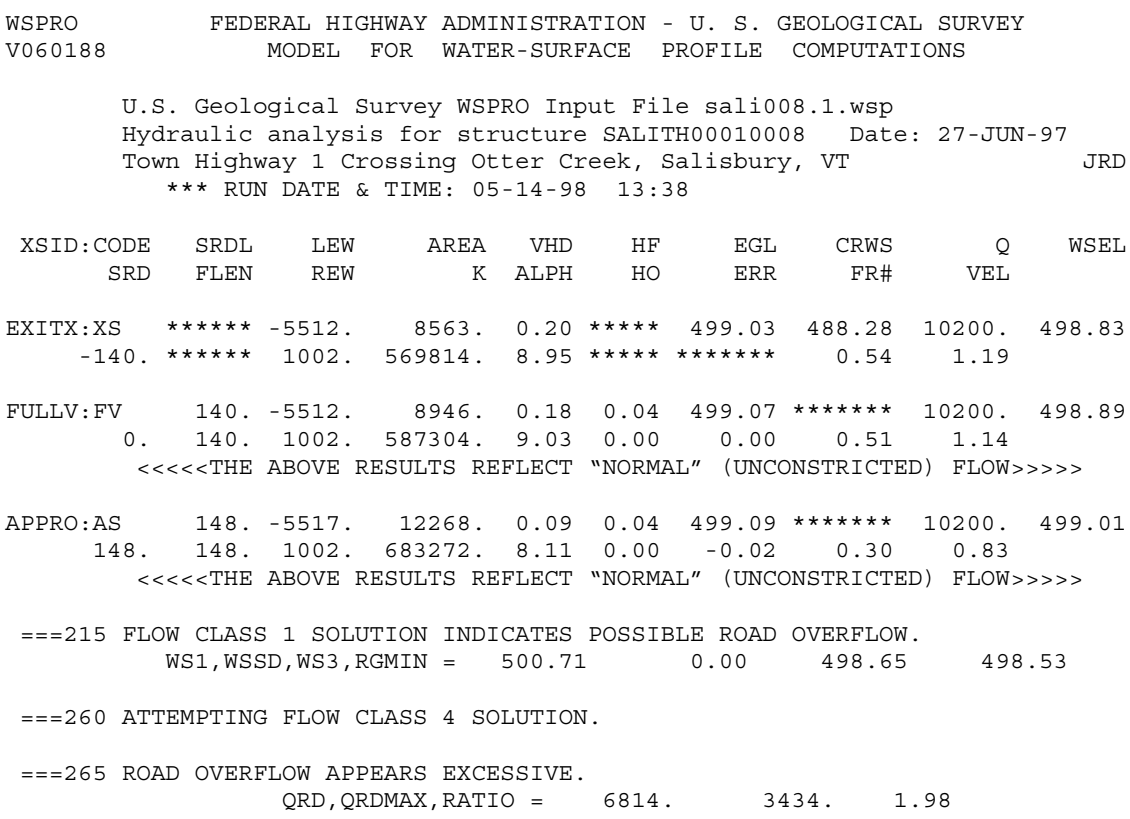


WSPRO OUTPUT FILE (continued)

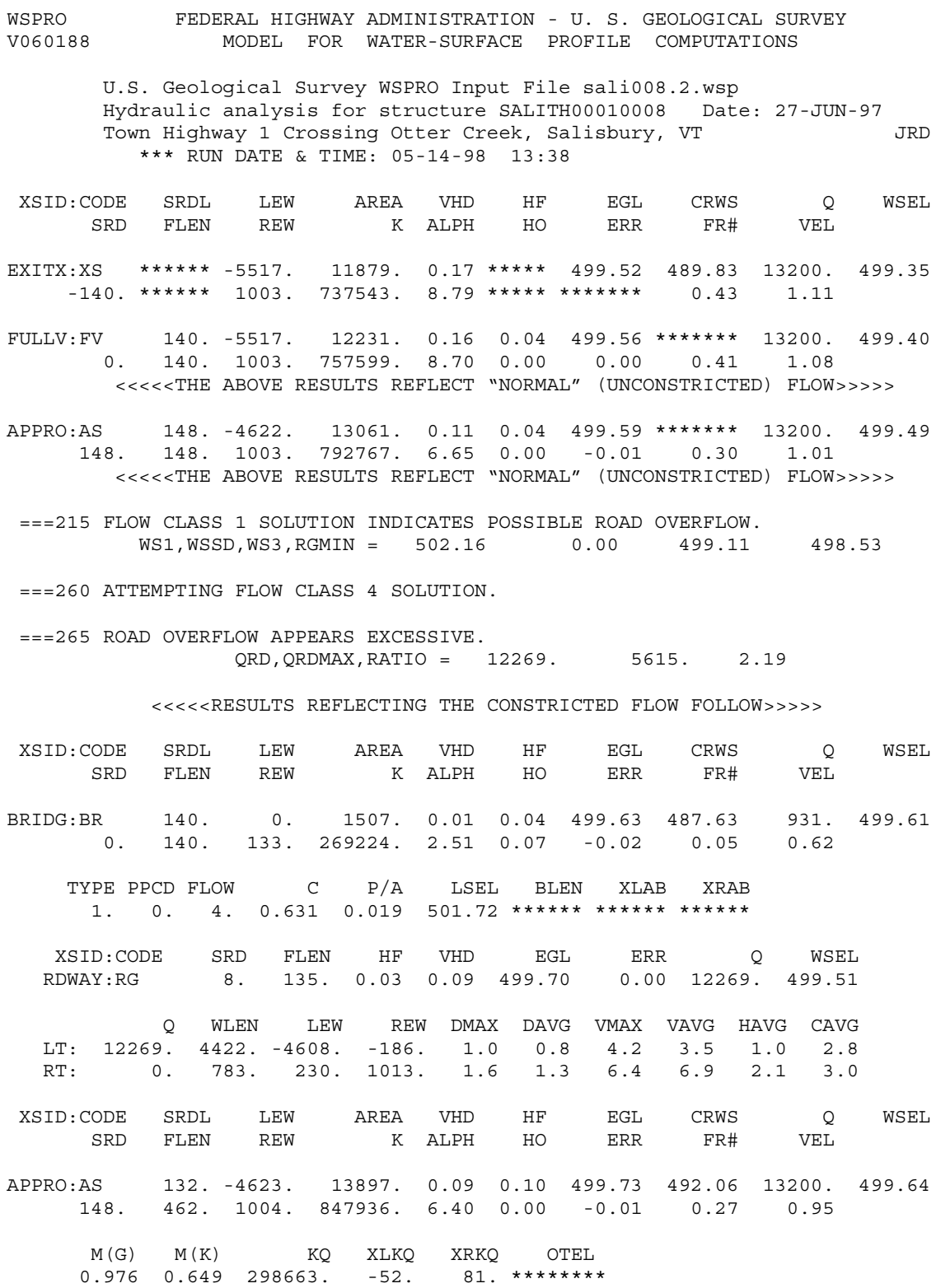

FIRST USER DEFINED TABLE.

\begin{tabular}{|c|c|c|c|c|c|c|c|c|}
\hline XSID : CODE & SRD & LEW & REW & Q & $\mathrm{K}$ & AREA & VEL & WSEL \\
\hline EXITX:XS & -140. & -5517. & 1003. & 13200 . & 737543. & 11879 . & 1.11 & 499.35 \\
\hline FULLV : FV & 0. & -5517 . & 1003. & 13200 . & 757599. & 12231. & 1.08 & 499.40 \\
\hline BRIDG : BR & 0 . & 0. & 133. & 931. & 269224 . & 1507 . & 0.62 & 499.61 \\
\hline RDWAY : RG & 8. & 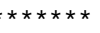 & 12269 . & 12269 . & 0. & 0 & 2.00 & 499.51 \\
\hline APPRO: AS & 148. & -4623 & 1004 . & 13200 . & 847936 . & 13897. & 0.95 & 499.64 \\
\hline XSID : CODE & XLKQ & XRKQ & & & & & & \\
\hline APPRO : AS & -52 & 81. & 298663 & & & & & \\
\hline
\end{tabular}

SECOND USER DEFINED TABLE.

$\begin{array}{lcrrrrrrrr}\text { XSID : CODE } & \text { CRWS } & \text { FR\# } & \text { YMIN } & \text { YMAX } & \text { HF } & \text { HO } & \text { VHD } & \text { EGL } & \text { WSEL } \\ \text { EXITX: }: \text { S } & 489.83 & 0.43 & 478.38 & 508.03 * * * * * * * * * * & 0.17 & 499.52 & 499.35 \\ \text { FULLV:FV } & * * * * * * * * & 0.41 & 478.38 & 508.03 & 0.04 & 0.00 & 0.16 & 499.56 & 499.40 \\ \text { BRIDG : BR } & 487.63 & 0.05 & 484.17 & 501.79 & 0.04 & 0.07 & 0.01 & 499.63 & 499.61 \\ \text { RDWAY: RG } & * * * * * * * * * * * * * * * & 498.53 & 508.00 & 0.03 * * * * * * & 0.09 & 499.70 & 499.51 \\ \text { APPRO:AS } & 492.06 & 0.27 & 479.97 & 508.03 & 0.10 & 0.00 & 0.09 & 499.73 & 499.64\end{array}$


WSPRO OUTPUT FILE (continued)

WSPRO

V060188
FEDERAL HIGHWAY ADMINISTRATION - U. S. GEOLOGICAL SURVEY MODEL FOR WATER-SURFACE PROFILE COMPUTATIONS

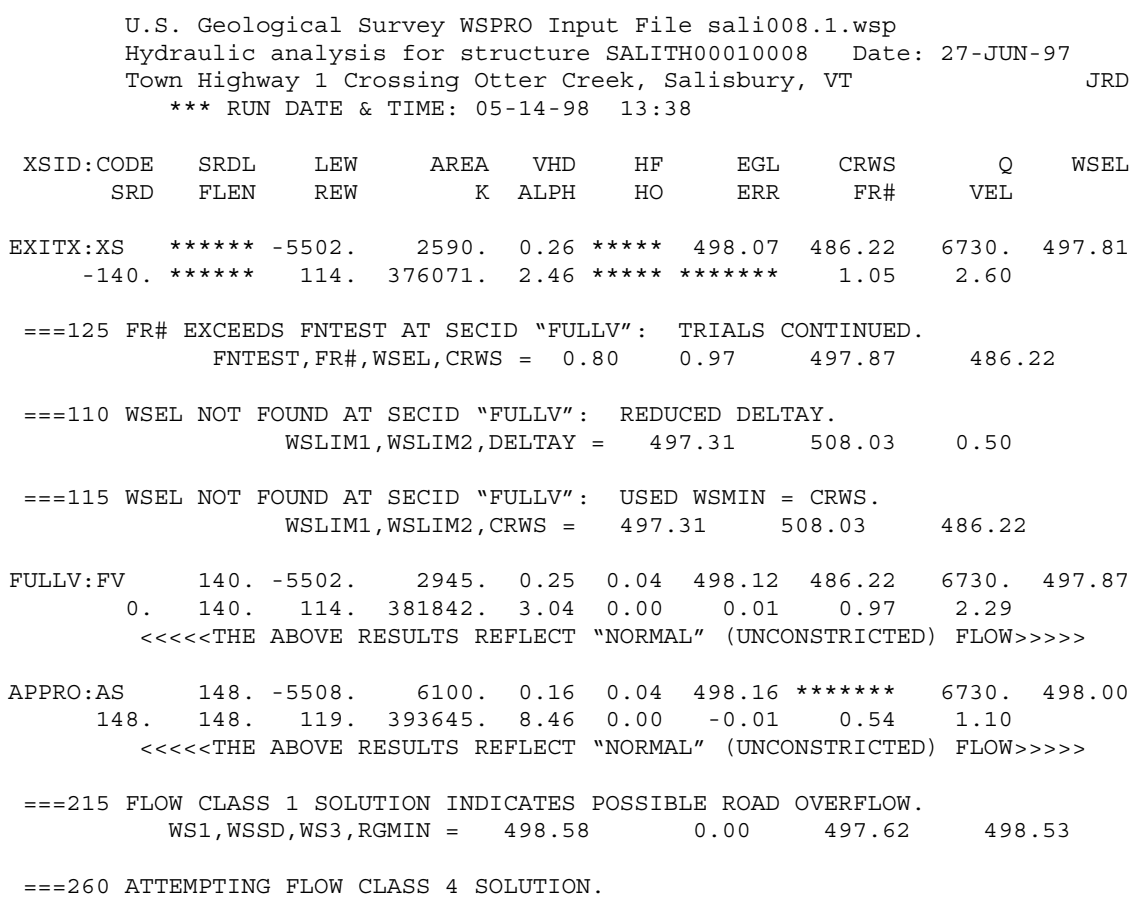




\section{APPENDIX C: \\ HISTORICAL DATA FORM}




\section{Structure Number SALITH00010008}

\section{General Location Descriptive}

Data collected by (First Initial, Full last name) $\underline{\text { L. }}$. Medalie

Date $(M M / D D / Y Y)+12 / 15 / \underline{95}$

Highway District Number (I - 2; nn) $\mathbf{0 5}$

Town (FIPS place code; I - 4; nnnnn) $\mathbf{6 2 5 7 5}$

Waterway (I - 6) OTTER CREEK

Route Number C2001

Topographic Map Cornwall

Latitude (I - 16; nnnn.n) $\mathbf{4 3 5 5 2}$
County (FIPS county code; I - 3; nnn)

Mile marker (I - 11; nnn.nnn) $\mathbf{0 0 0 0 0 0}$

Road Name (I - 7): -

Vicinity (I - 9) 0.7 MI TO JCT W CL3 TH14

Hydrologic Unit Code: 2010002

Longitude (i - 17; nnnnn.n) 73105

\section{Select Federal Inventory Codes}

FHWA Structure Number $(I-8) \underline{10011700080117}$

Maintenance responsibility $(I-21 ; n n) \quad \mathbf{0 3} \quad$ Maximum span length $(I-48 ; n n n n) \underline{\mathbf{0 0 7 1}}$

Year built (I - 27; YYYY) 1865

Structure length (I - 49; nnnnnn) $\underline{\mathbf{0 0 0 1 5 6}}$

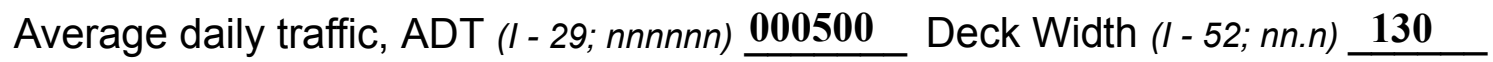

Year of ADT (I - 30; YY) $\mathbf{9 2}$

Channel \& Protection $(I-61 ; n) \underline{\mathbf{6}}$

Opening skew to Roadway $(I-34 ; n n) \quad \mathbf{0 0}$

Waterway adequacy $(I-71 ; n) \quad 5$

Operational status $(I-41 ; X) \underline{P}$

Underwater Inspection Frequency (I - 92B; XYY) Y24

Structure type (I - 43; nnn) $\mathbf{7 1 0}$

Year Reconstructed (I - 106) 1966

Approach span structure type $(I-44 ; n n n) \quad \mathbf{0 0 0}$

Clear span (nnn.n ft) $\mathbf{1 3 2 . 4}$

Number of spans (I - 45; nnn) $\underline{\mathbf{0 0 2}}$

Vertical clearance from streambed (nnn.n ft) 16

Number of approach spans (I - 46; nnnn) $\underline{\mathbf{0 0 0 0}}$ Waterway of full opening $\left(n n n . n \mathrm{ft}^{2}\right) \underline{\mathbf{1 8 1 0}}$

Comments:

According to the structural inspection report dated $12 / 8 / 94$, the structure is a wooden lattice work thrutruss covered bridge. The LABUT and its backwall are concrete. They have minor cracks and spalls. The RABUT is grouted laid up stone with a concrete backwall and concrete pads under the bearing areas. The back-wall has a few cracks and spalls overall. The pier is a solid concrete column. The bearing blocks and bearing beams under the bottom chord, on top of the pier, were originally creosote coated, except for a couple of blocks on the right side. Both abutments have small earth embankments in front of them, with a few boulders showing. Some possible local scour is noted around the pier. 


\section{Bridge Hydrologic Data}

Is there hydrologic data available? $\underline{\mathbf{N}}$ if No, type ctrl-n $h \quad$ VTAOT Drainage area $\left(m i^{2}\right)$ : -

Terrain character:

Stream character \& type: -

Streambed material:

Discharge Data (cfs):

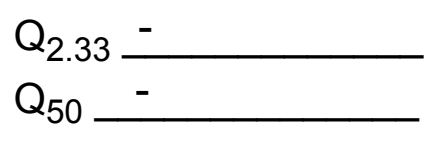

Record flood date $(M M / D D / Y Y):-{ }^{\prime}-$
Estimated Discharge $(c f s):-$

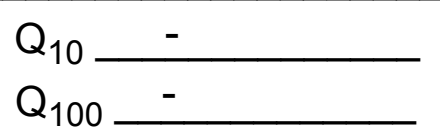

$\mathrm{Q}_{25}$

Water surface elevation $(f t):-$ $(\mathrm{ft} / \mathrm{s}):$

Ice conditions (Heavy, Moderate, Light) : -

Debris (Heavy, Moderate, Light):

The stage increases to maximum highwater elevation (Rapidly, Not rapidly):

The stream response is (Flashy, Not flashy):

Describe any significant site conditions upstream or downstream that may influence the stream's stage: -

Watershed storage area (in percent):

The watershed storage area is: - (1-mainly at the headwaters; 2- uniformly distributed; 3-immediatly upstream oi the site)

Water Surface Elevation Estimates for Existing Structure:

\begin{tabular}{|l|l|l|l|l|l|}
\hline Peak discharge frequency & $Q_{2.33}$ & $Q_{10}$ & $Q_{25}$ & $Q_{50}$ & $Q_{100}$ \\
Water surface elevation (ft)) & - & - & - & - & - \\
Velocity (ft/sec) & - & - & - & - & - \\
\hline
\end{tabular}

Long term stream bed changes: -

Is the roadway overtopped below the $\mathrm{Q}_{100}$ ? (Yes, No, Unknown): $\mathbf{U}$ Frequency: -

Relief Elevation (ft):

Discharge over roadway at $Q_{100}\left(f^{3} / \mathrm{sec}\right)$ :

Are there other structures nearby? (Yes, No, Unknown): Upstream distance (miles): Town: If No or Unknown, type ctrl-n os Highway No. :Structure No. :Year Built:

Clear span (ft): Clear Height (ft): Full Waterway $\left(f^{2}\right)$ : 
Downstream distance (miles): Town: Year Built:

Highway No. : Structure No. : Structure Type:

Clear span (ft): Clear Height $(f t)$ : Full Waterway $\left(f t^{2}\right)$ :

Comments:

\section{USGS Watershed Data}

Watershed Hydrographic Data

Drainage area $(D A) \stackrel{542.69}{\mathrm{mi}^{2}}$ Lake/pond/swamp area 23.24 $\mathrm{mi}^{2}$

Watershed storage (ST) 4.28

Bridge site elevation $\mathbf{3 4 0} \mathrm{ft}$ $\%$

Main channel length $\mathbf{7 3 . 2 6}$ $\mathrm{mi}$

$10 \%$ channel length elevation $\quad \mathbf{3 5 0}$ $\mathrm{ft} \quad 85 \%$ channel length elevation 659 $\mathrm{ft}$

Main channel slope (S) $\quad \mathbf{5 . 6 2} \mathrm{ft} / \mathrm{mi}$

Watershed Precipitation Data

Average site precipitation in Average headwater precipitation in

Maximum 2yr-24hr precipitation event $(124,2)$ in

Average seasonal snowfall (Sn) $\mathrm{ft}$ 


\section{Bridge Plan Data}

Are plans available? $\underline{\mathbf{Y}}$ If no, type ctrl- $n$ pl Date issued for construction (MM / YYYY):

Project Number

Minimum channel bed elevation:

Low superstructure elevation: USLAB DSLAB USRAB DSRAB Benchmark location description:

Ther are no elevations noted on the plans.

Reference Point (MSL, Arbitrary, Other):

Datum (NAD27, NAD83, Other):

Foundation Type: 2* (1-Spreadfooting; 2-Pile; 3- Gravity; 4-Unknown)

If 1: Footing Thickness _ _ Footing bottom elevation: -

If 2: Pile Type: $\underline{\mathbf{2}}$ (1-Wood; 2-Steel or metal; 3-Concrete) Approximate pile driven length: $\mathbf{1 4 0}$

If 3: Footing bottom elevation:

Is boring information available? $\underline{\mathbf{Y}}$ If no, type ctrl-n bi Number of borings taken: $\underline{\mathbf{3}}$

Foundation Material Type: 1 (1-regolith, 2-bedrock, 3-unknown)

Briefly describe material at foundation bottom elevation or around piles:

Very soft clay for material around the piles at the pier.

Comments:

*Five piles were driven at the pier. There is a 2-foot thick footing on the LABUT and no footing on the RABUT. 


\section{Cross-sectional Data}

Is cross-sectional data available? $\mathbf{N}$ If no, type ctrl-n xs

Source (FEMA, VTAOT, Other)? -

Comments:

There is no cross section information available.

\begin{tabular}{|l|l|l|l|l|l|l|l|l|l|l|l|}
\hline Station & - & - & - & - & - & - & - & - & - & - & - \\
\hline Feature & - & - & - & - & - & - & - & - & - & - & - \\
\hline $\begin{array}{l}\text { Low chord } \\
\text { elevation }\end{array}$ & - & - & - & - & - & - & - & - & - & - & - \\
\hline $\begin{array}{l}\text { Bed } \\
\text { elevation }\end{array}$ & - & - & - & - & - & - & - & - & - & - & - \\
\hline $\begin{array}{l}\text { Low chord } \\
\text { to bed }\end{array}$ & - & - & - & - & - & - & - & - & - & - & - \\
\hline Station & - & - & - & - & - & - & - & - & - & - & - \\
\hline Feature & - & - & - & - & - & - & - & - & - & - & - \\
\hline $\begin{array}{l}\text { Low chord } \\
\text { elevation }\end{array}$ & - & - & - & - & - & - & - & - & - & - & - \\
\hline $\begin{array}{l}\text { Bed } \\
\text { elevation }\end{array}$ & - & - & - & - & - & - & - & - & - & - & - \\
\hline $\begin{array}{l}\text { Low chord } \\
\text { to bed }\end{array}$ & - & - & - & - & - & - & - & - & - & - & - \\
\hline
\end{tabular}

Source (FEMA, VTAOT, Other)?

Comments: -

\begin{tabular}{|l|l|l|l|l|l|l|l|l|l|l|l|}
\hline Station & - & - & - & - & - & - & - & - & - & - & - \\
\hline Feature & - & - & - & - & - & - & - & - & - & - & - \\
\hline $\begin{array}{l}\text { Low chord } \\
\text { elevation }\end{array}$ & - & - & - & - & - & - & - & - & - & - & - \\
\hline $\begin{array}{l}\text { Bed } \\
\text { elevation }\end{array}$ & - & - & - & - & - & - & - & - & - & - & - \\
\hline $\begin{array}{l}\text { Low chord } \\
\text { to bed }\end{array}$ & - & - & - & - & - & - & - & - & - & - & - \\
\hline Station & - & - & - & - & - & - & - & - & - & - & - \\
\hline Feature & - & - & - & - & - & - & - & - & - & - & - \\
\hline $\begin{array}{l}\text { Low chord } \\
\text { elevation }\end{array}$ & - & - & - & - & - & - & - & - & - & - & - \\
\hline $\begin{array}{l}\text { Bed } \\
\text { levation }\end{array}$ & - & - & - & - & - & - & - & - & - & - & - \\
\hline $\begin{array}{l}\text { Low chord } \\
\text { to bed }\end{array}$ & - & - & - & - & - & - & - & - & - & - & - \\
\hline
\end{tabular}


APPENDIX D:

LEVEL I DATA FORM 
U. S. Geological Survey

Bridge Field Data Collection and Processing Form

Qa/Qc Check by: EW Date: $9 / 27 / 96$

\section{Structure Number SALITH00010008} Computerized by: $\underline{\mathbf{E W}}$ Date: $\underline{\mathbf{9} / 27 / 96}$

Reviewd by: $\quad$ EMB Date: $\underline{2 / 27 / 98}$

\section{A. General Location Descriptive}

1. Data collected by (First Initial, Full last name) L. MEDALIE

2. Highway District Number $\mathbf{0 5}$

County ADDISON (001)

Waterway (I - 6) OTTER CREEK

Route Number TH 1
Date $(M M / D D / Y Y) \underline{06} / \underline{12} / \underline{1996}$

Mile marker 000000

Town SALISBURY (62575)

Road Name -

Hydrologic Unit Code: $\mathbf{0 2 0 1 0 0 0 2}$

3. Descriptive comments:

This structure is a covered bridge located 0.7 mile from the junction of TH 1 with TH14. A local resident mentioned that this road (Town Highway 1) has been overtopped 5 or 6 times by streamflows since August of 1995. The left road approach is gravel fill and has been washed out at least once during high flows.

\section{B. Bridge Deck Observations}
4. Surface cover.
RBUS 4
LBDS 4
RBDS 4
Overall 4

(2b us,ds,lb,rb: 1- Urban; 2- Suburban; 3- Row crops; 4- Pasture; 5- Shrub- and brushland; 6- Forest; 7- Wetland)
5. Ambient water surface... US 1
UB 1
DS 1
(1- pool; 2- riffle)

6. Bridge structure type 2 (1- single span; 2- multiple span; 3- single arch; 4- multiple arch; 5-cylindrical culvert; 6- box culvert; or 7- other)
7. Bridge length 156
(feet)
Span length $\mathbf{7 1}$
(feet)
Bridge width 13 (feet)

\section{Road approach to bridge:}
8. LB 1 RB 1
( 0 even, 1- lower, 2- higher)
9. $L B \_$ 2 RB 1
(1- Paved, 2- Not paved)

10. Embankment slope (run / rise in feet / foot)

US left

US right

\begin{tabular}{|c|c|c|c|}
\hline \multicolumn{2}{|c|}{ Protection } & \multirow{2}{*}{ 13.Erosion } & 14.Severity \\
\hline 11.Type & 12.Cond. & $\underline{\mathbf{2}}$ & $\mathbf{1}$ \\
\hline $\mathbf{0}$ & - & $\mathbf{2}$ & $\mathbf{1}$ \\
\hline $\mathbf{1}$ & $\mathbf{1}$ & $\underline{\mathbf{2}}$ & $\mathbf{1}$ \\
\hline $\mathbf{0}$ & - & $\underline{\mathbf{2}}$ & $\underline{\mathbf{1}}$ \\
\hline $\mathbf{2}$ & $\mathbf{1}$ & $\underline{\mathbf{2}}$ & $\underline{\mathbf{1}}$ \\
\hline
\end{tabular}

Bank protection types: 0- none; 1- < 12 inches,

2- $<36$ inches; $3-<48$ inches;

4- < 60 inches; 5- wall / artificial levee

Bank protection conditions: 1- good; 2- slumped;

3- eroded; 4- failed

Erosion: 0 - none; 1- channel erosion; 2 -

road wash; 3- both; 4- other

Erosion Severity: 0 - none; 1- slight; 2- moderate; 3- severe

\section{Channel approach to bridge (BF):}

15. Angle of approach: $\mathbf{1 0}$

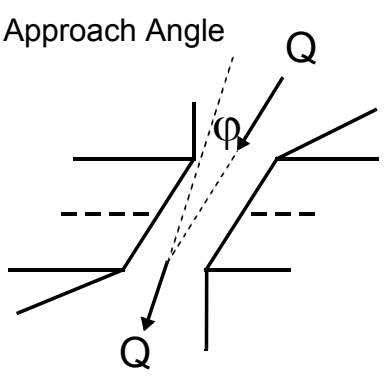

17. Channel impact zone 1:

Where? RB $(L B, R B)$

Range? 75 feet DS

Channel impact zone 2:

Where? _ _ $(L B, R B)$

Range? - $\quad$ feet (US, UB, DS) to -

Impact Severity: 0- none to very slight; 1- Slight; 2- Moderate; 3- Severe
, DS) to - feet -

16. Bridge skew: $\mathbf{2 0}$ Bridge Skew Angle

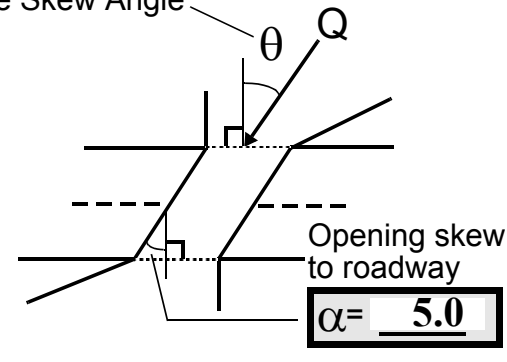

\section{Exist? $\mathbf{Y}(Y$ or $N)$}

Severity 1

(US, UB, DS) to 175 feet

Exist? $\underline{\mathbf{N}}(\mathrm{Y}$ or $N)$

Severity - 
18. Bridge Type: $1 \mathbf{b}$

1a- Vertical abutments with wingwalls

$1 \mathrm{~b}$ - Vertical abutments without wingwalls

2- Vertical abutments and wingwalls, sloping embankment Wingwalls parallel to abut. face

3- Spill through abutments

4- Sloping embankment, vertical wingwalls and abutments

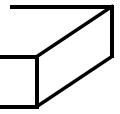

Wingwall angle less than $90^{\circ}$.
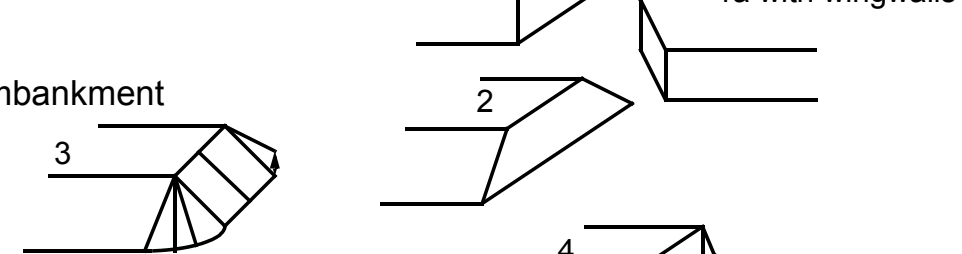

19. Bridge Deck Comments (surface cover variations, measured bridge and span lengths, bridge type variations, approach overflow width, etc.)

4: The left overbank downstream is a wet, low lying area near the river approximately 100 feet wide with pasture beyond 100 feet from the river. The area near the bridge on the left bank upstream is an 80 square foot dirt parking lot with wetland further toward the left side of the valley. All of the overbank areas are saturated with water, but classified as pasture because vegetation is grass.

7: The bridge length, span length, and bridge width measured at the time of this assessment were 153.5 feet, 65 feet, and 15.1 feet, respectively. The length of the span was measured between the pier and the left abutment and the width was measured from the outside edges of the horizontal planks.

11: The LBDS protection is a single boulder, in which RM2 is chiseled, placed at the end of the bridge beneath the road surface. The road is built-up with stone fill. The stone fill extends 2 to 4 feet along the road edges on either side.

\section{Upstream Channel Assessment}

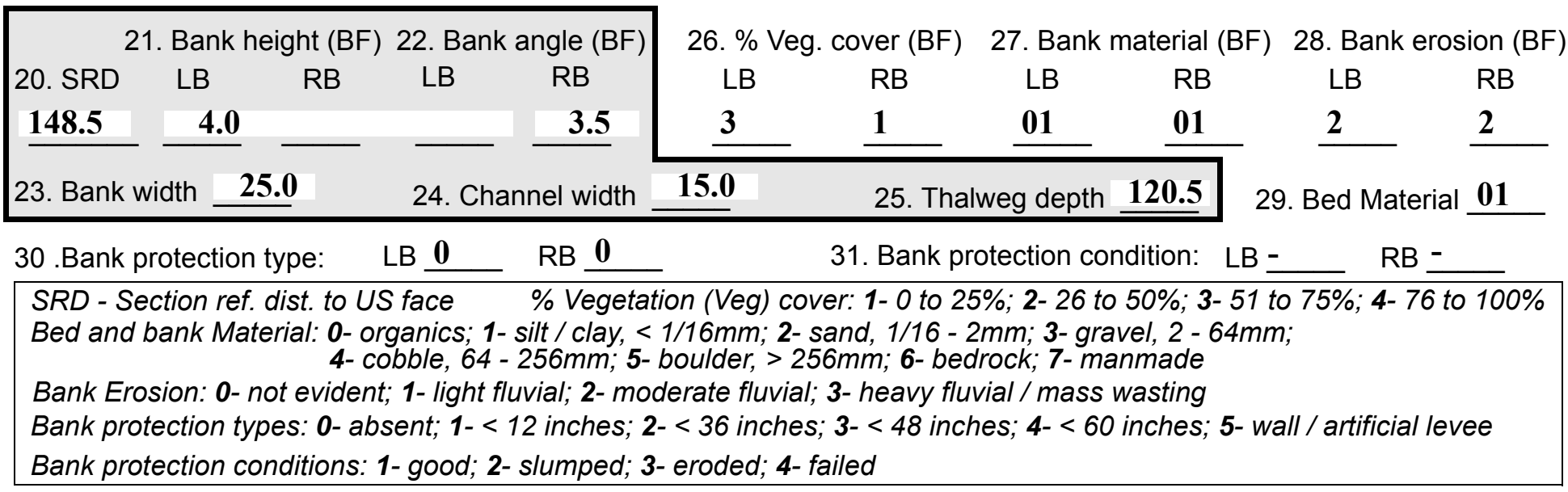

32. Comments (bank material variation, minor inflows, protection extent, etc.):

26: A few large trees are observed along the left bank.

Water depths vary from the approach to the upstream end of the debris pile:

At 8 feet from left bank, the water depth changes from 7 feet to 12 feet.

At 8 feet from right bank, the water depth changes from 11 feet to 13 feet.

A culvert drainage channel for run-off from the parking area enters the left bank of the channel from 23 feet to 29 feet upstream of bridge. The culvert is located 75 feet from the left bank of channel.

A boat launch exists along the upstream left bank from 75 feet to 55 feet from bridge. 
33.Point/Side bar present? $\mathbf{N}(Y$ or $N$. if $N$ type ctrl-n pb)34. Mid-bar distance: -

35. Mid-bar width:

36. Point bar extent: feet (US, UB) to feet (US, UB, DS) positioned $\%$ LB to $\% \mathrm{RB}$

37. Material:

38. Point or side bar comments (Circle Point or Side; Note additional bars, material variation, status, etc.):

NO POINT BARS

39. Is a cut-bank present? $\underline{\mathbf{N}}$ (Y or if $\mathrm{N}$ type ctrl-n cb)

40. Where? (LB or $R B)$

41. Mid-bank distance: -

42. Cut bank extent: feet (US, UB) to feet (US, UB, DS)

43. Bank damage: (1- eroded and/or creep; 2- slip failure; 3- block failure)

44. Cut bank comments (eg. additional cut banks, protection condition, etc.):

NO CUT BANKS

Channel is straight for approximately 2000 feet upstream.

45. Is channel scour present? $\mathbf{N}$ (Yor if $N$ type ctrl-n cs) 46. Mid-scour distance: -

47. Scour dimensions: Length Width Depth : -

Position \%LB to $\% \mathrm{RB}$

48. Scour comments (eg. additional scour areas, local scouring process, etc.):

NO CHANNEL SCOUR

49. Are there major confluences? $\mathbf{N}$ ( $Y$ or if $N$ type ctrl-n $m c)$

51. Confluence 1: Distance 52. Enters on (LB or $R B)$ Confluence 2: Distance Enters on (LB or $R B)$

54. Confluence comments (eg. confluence name):

NO MAJOR CONFLUENCES

\section{Under Bridge Channel Assessment}

55. Channel restraint (BF)? LB 2 (1- natural bank; 2- abutment; 3- artificial levee)

\begin{tabular}{|cccc}
\hline \multicolumn{2}{|c}{56. Height (BF) } & \multicolumn{2}{c}{57 Angle (BF) } \\
LB & RB & LB & RB \\
$\mathbf{1 0 0 . 0}$ & & & $\mathbf{1 5 . 0}$ \\
\hline
\end{tabular}

58. Bank width (BF) -

59. Channel width -

61. Material (BF)

LB RB

62. Erosion (BF)

$2 \quad 7$

LB RB

53. Type(1- perennial; 2- ephemeral)

Type (1-perennial; 2- ephemeral)

Bed and bank Material: 0- organics; 1- silt / clay, < 1/16mm; 2- sand, 1/16 - 2mm; 3- gravel, 2 - 64mm; 4- cobble, 64 - 256mm; 5- boulder, > 256mm; 6- bedrock; 7- manmade

Bank Erosion: 0- not evident; 1- light fluvial; 2- moderate fluvial; 3- heavy fluvial / mass wasting

64. Comments (bank material variation, minor inflows, protection extent, etc.):

312

A few stones have been placed along the left bank. 
65. Debris and Ice Is there debris accumulation?

$(Y$ or $N)$ 66. Where? $\underline{Y}$

(1- Upstream; 2- At bridge; 3- Both)

67. Debris Potential $\underline{3}$

( 1- Low; 2- Moderate; 3- High)

68. Capture Efficiency 3

(1-Low; 2- Moderate; 3- High)

69. Is there evidence of ice build-up? $\underline{3}$ (Y or $N)$

Ice Blockage Potential $\underline{Y}$

(1-Low; 2- Moderate; 3- High)

70. Debris and Ice Comments:

3

A large debris pile exists across the entire channel width, just upstream of bridge. Debris also is caught in branches 3 to 4 feet above the road (as a result of weir flow). Debris is caught in trees along the banks about 4 to 5 feet above the water surface.

\begin{tabular}{|l|l|l|l|l|l|c|c|c|}
\hline Abutments & $\begin{array}{c}\text { 71. Attack } \\
\angle \text { (BF) }\end{array}$ & $\begin{array}{c}\text { 72. Slope } \angle \\
\text { (Qmax) }\end{array}$ & $\begin{array}{l}\text { 73. Toe } \\
\text { loc. (BF) }\end{array}$ & $\begin{array}{c}\text { 74. Scour } \\
\text { Condition }\end{array}$ & $\begin{array}{r}\text { 75. Scour } \\
\text { depth }\end{array}$ & $\begin{array}{c}\text { 76. Exposure } \\
\text { depth }\end{array}$ & 77. Material & 78. Length \\
\hline LABUT & The & trees & all & have & visi- & ble & scars & $\mathbf{9 0 . 0}$ \\
\hline RABUT & abou & $\mathbf{t 9}$ & feet & & & abov & e the & - \\
\hline
\end{tabular}

Pushed: $L B$ or RB

Toe Location (Loc.): 0- even, 1- set back, 2- protrudes

Scour cond.: 0- not evident; 1- evident (comment); 2- footing exposed; 3-undermined footing; 4- piling exposed; 5- settled; 6- failed

Materials: 1- Concrete; 2- Stone masonry or drywall; 3- steel or metal; 4- wood

79. Abutment comments (eg. undermined penetration, unusual scour processes, debris, etc.):

channel bed, or 5 feet above the present water surface.

0

70

0

0

1

0

90

80. Wingwalls:

$\begin{array}{cccc}\text { Exist? Material? } & \text { Scour } & \text { Scour Exposure } & \text { Angle? Length? } \\ \text { Condition? depth? } & \text { depth? }\end{array}$

USLWW: 0

0

USRWW: _

-

DSLWW:

2

DSRWW: on

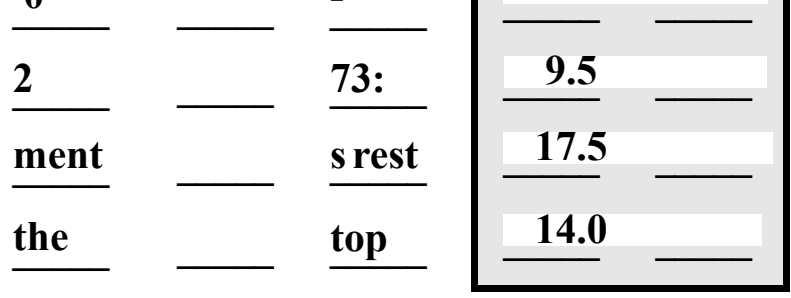

Wingwall materials: 1- Concrete; 2- Stone masonry or drywall; 3- steel or metal; 4-wood

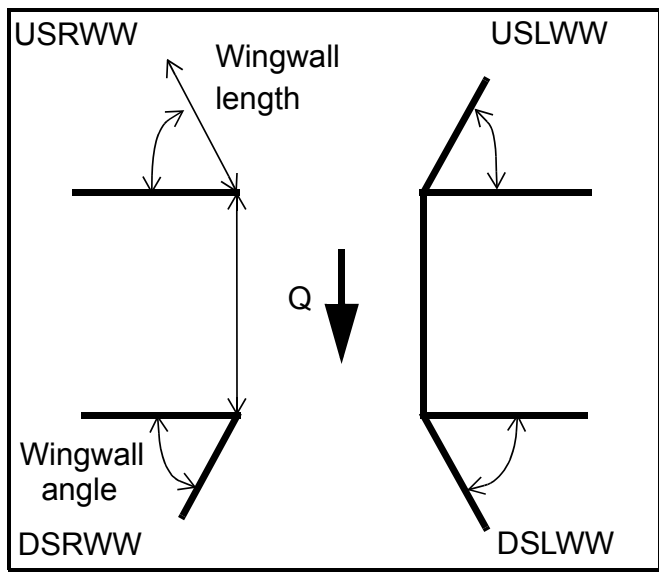

82. Bank / Bridge Protection:

\begin{tabular}{|l|l|l|l|l|l|l|l|l|}
\hline Location & USLWW & USRWW & LABUT & RABUT & LB & RB & DSLWW & DSRWW \\
\hline Type & of & ks. & left & t is & e & righ & men & e \\
\hline Condition & the & $\mathbf{7 7}$ & abut & con- & and & $\mathbf{t}$ & $\mathbf{t}$ is & mas \\
\hline Extent & ban & The & men & cret & the & abut & ston & onr \\
\hline
\end{tabular}

Bank / Bridge protection types: 0- absent; 1- < 12 inches; 2- < 36 inches; 3- < 48 inches; 4- < 60 inches; 
83. Wingwall and protection comments (eg. undermined penetration, unusual scour processes, etc.): $y$, capped with concrete.

$\mathbf{N}$

Piers:

84. Are there piers? _ _ (Y or if $N$ type ctrl-n pr)

\begin{tabular}{|l|l|l|l|l|l|l|l|}
\hline \multirow{2}{*}{$\begin{array}{l}85 . \\
\text { Pier no. }\end{array}$} & \multicolumn{3}{|c|}{ width (w) feet } & \multicolumn{3}{c|}{ elevation (e) feet } \\
\cline { 2 - 9 } & w1 & w2 & w3 & e@w1 & e@w2 & e@w3 \\
\hline Pier 1 & - & - & - & - & - & - \\
\hline Pier 2 & - & $\mathbf{1 . 0}$ & $\mathbf{3 . 0}$ & - & $\mathbf{4 8 7 . 3}$ & $\mathbf{4 9 1 . 6}$ \\
\hline Pier 3 & - & - & - & - & - & - \\
\hline Pier 4 & - & - & - & - & - & - \\
\hline
\end{tabular}

\begin{tabular}{|c|c|c|c|c|}
\hline Level 1 Pier Descr. & 1 & 2 & 3 & 4 \\
\hline 86. Location (BF) & - & $\mathbf{N}$ & - & - \\
\hline 87. Type & - & - & - & - \\
\hline 88. Material & $\mathbf{N}$ & - & $\mathbf{0}$ & - \\
\hline 89. Shape & - & - & - & - \\
\hline 90. Inclined? & - & - & - & - \\
\hline 91. Attack $\angle(B F)$ & - & - & 1 & Left \\
\hline 92. Pushed & - & - & 1 & bank \\
\hline 93. Length (feet) & - & - & - & - \\
\hline 94. \# of piles & $\mathbf{N}$ & - & 4 & pro- \\
\hline 95. Cross-members & - & - & $\mathbf{0}$ & tec- \\
\hline 96. Scour Condition & - & - & - & tion \\
\hline 97. Scour depth & - & - & - & con- \\
\hline 98. Exposure depth & - & $\mathbf{0}$ & - & sists \\
\hline
\end{tabular}

LFP, LTB, LB, MCL, MCM, MCR, RB, RTB, RFP

1- Solid pier, 2- column, 3- bent

1-Wood; 2- concrete; 3- metal; 4- stone

1- Round; 2- Square; 3- Pointed

Y-yes; $N$ - no

$L B$ or $R B$

0- none; 1- laterals; 2- diagonals; 3- both

0- not evident; 1- evident (comment);

2- footing exposed; 3- piling exposed;

4- undermined footing; 5- settled; 6-failed 
99. Pier comments (eg. undermined penetration, protection and protection extent, unusual scour processes, etc.):

of two groups of stones about 5 feet apart, each extending about 4 feet across the bank and 2 feet down.

100.

\section{E. Downstream Channel Assessment}

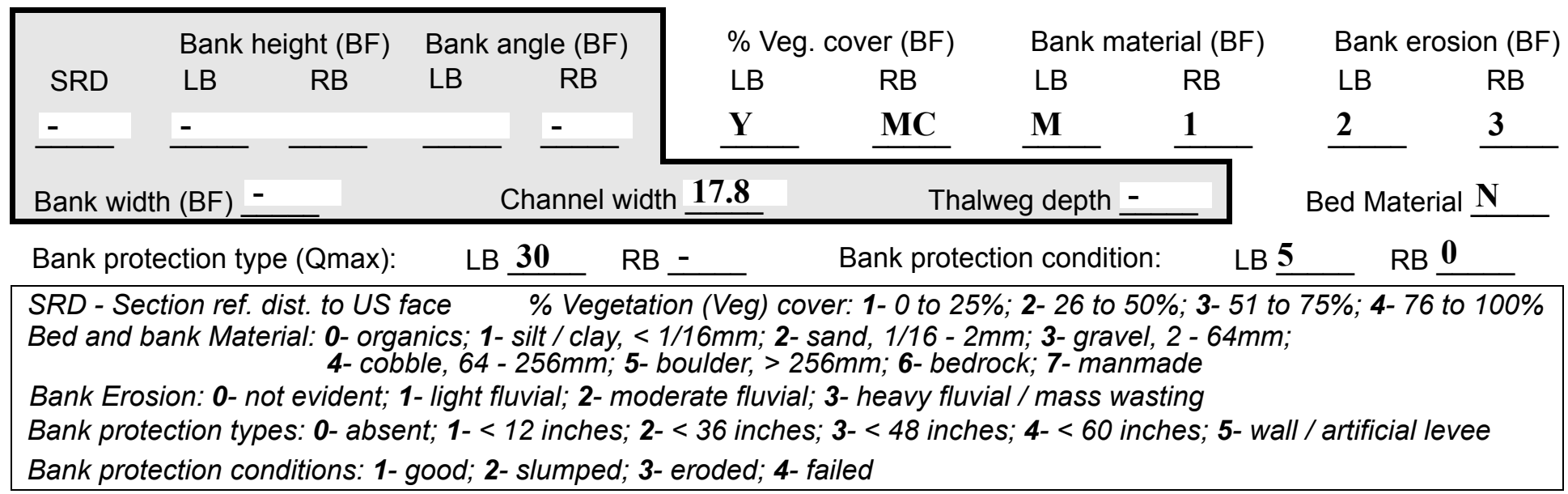

Comments (eg. bank material variation, minor inflows, protection extent, etc.):

0

101. Is a drop structure present? _ _ ( or $N$, if $N$ type ctrl-n ds) 102. Distance: ___ feet
103. Drop: - feet
104. Structure material:
(1- steel sheet pile; 2- wood pile; 3- concrete; 4- other)

105. Drop structure comments (eg. downstream scour depth): 
Point bar extent: feet (US, UB, DS) to feet (US, UB, DS) positioned $\%$ LB to $\%$ RB

Material:

Point or side bar comments (Circle Point or Side; note additional bars, material variation, status, etc.):

Is a cut-bank present? (Y or if $N$ type ctrl- $n$ cb) Where? (LB or $R B)$ Mid-bank distance: 94:

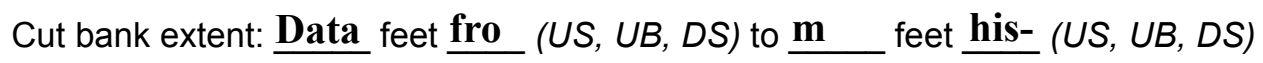

Bank damage: tori (1- eroded and/or creep; 2- slip failure; 3- block failure)

Cut bank comments (eg. additional cut banks, protection condition, etc.):

cal form.

Is channel scour present? ( $Y$ or if $N$ type ctrl-n cs)

Mid-scour distance:

Scour dimensions: Length Depth:

Positioned $\%$ LB to $\underline{\mathbf{3}} \%$ RB Scour comments (eg. additional scour areas, local scouring process, etc.): 3

01

01

2

Are there major confluences? 2 ( $Y$ or if $N$ type ctrl-n $m c)$ Confluence 1: Distance $\underline{0}$ Enters on $\underline{\mathbf{0}}$ (LB or RB) How many? 102

Confluence 2: Distance Enters on $\underline{\mathbf{A t}}$ (LB or RB)

Type (1-perennial; 2- ephemeral)

Confluence comments (eg. confluence name):

Type 10 (1- perennial; 2- ephemeral)

feet from left bank, the water depth changes from 10 feet to 13 feet to 16 feet between the downstream bridge face and 100 feet downstream. At 10 feet from right bank, the water depth changes from 10 feet to 12 feet to 8

\section{F. Geomorphic Channel Assessment}

107. Stage of reach evolution fee

1- Constructed

2- Stable

3- Aggraded

4- Degraded

5- Laterally unstable

6- Vertically and laterally unstable 
108. Evolution comments (Channel evolution not considering bridge effects; See HEC-20, Figure 1 for geomorphic descriptors):

t over the same 100 feet downstream from the downstream bridge face. At the center of the channel the water depth measured varied from 10 feet to greater than 16 feet from the downstream bridge face to 100 feet downstream. 


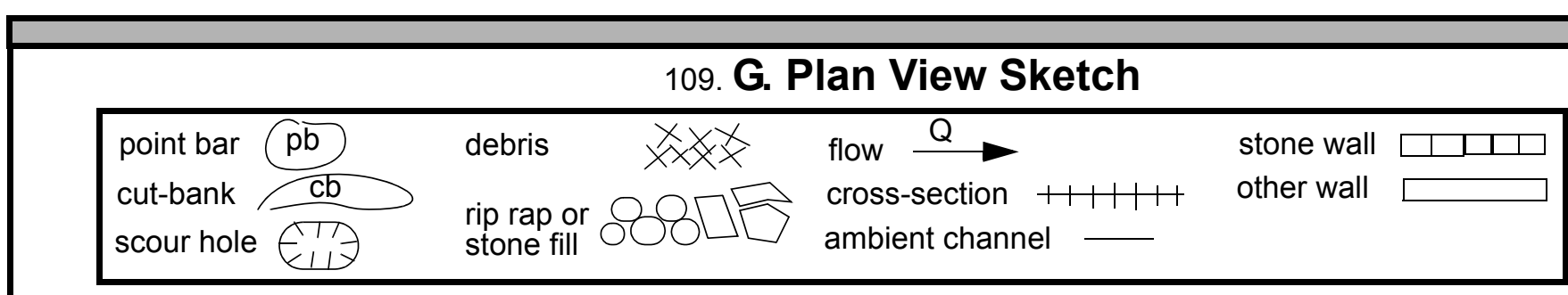


APPENDIX E:

SCOUR COMPUTATIONS 


\begin{tabular}{|c|c|c|c|}
\hline $\begin{array}{ll}\text { Structure Number: } & \text { SALITH00010008 } \\
\text { Road Number: } & \text { TH } 1 \\
\text { Stream: } & \text { Otter Creek }\end{array}$ & & $\begin{array}{l}\text { Town: } \\
\text { County: }\end{array}$ & $\begin{array}{l}\text { Salisbury } \\
\text { Addison }\end{array}$ \\
\hline Initials EMB & Checked: & RLB & \\
\hline \multicolumn{4}{|c|}{ Analysis of contraction scour, live-bed or clear water? } \\
\hline $\begin{array}{l}\text { Critical Velocity of Bed Material } \\
\text { VC=11.21*y1^0.1667*D50^0.33 with S } \\
\text { (Richardson and Davis, } 1995, \text { p. } 28\end{array}$ & $\begin{array}{l}\text { converted } \\
=2.65 \\
\text { eq. } 16)\end{array}$ & to Englis & sh units) \\
\hline \multicolumn{4}{|l|}{ Approach Section } \\
\hline Characteristic & $100 \mathrm{yr}$ & $500 \mathrm{yr}$ & other $Q$ \\
\hline Total discharge, cfs & 10200 & 13200 & 6730 \\
\hline Main Channel Area, ft2 & 1574 & 1617 & 1490 \\
\hline Left overbank area, ft2 & 11730 & 11223 & 7868 \\
\hline Right overbank area, ft2 & 742 & 1060 & 135 \\
\hline Top width main channel, ft & 120 & 120 & 120 \\
\hline Top width L overbank, ft & 5520 & 4601 & 5509 \\
\hline Top width $\mathrm{R}$ overbank, ft & 883 & 883 & 689 \\
\hline D50 of channel, ft & 0.000102 & 0.000102 & 0.000102 \\
\hline D50 left overbank, ft & -- & -- & -- \\
\hline D50 right overbank, ft & -- & -- & -- \\
\hline y1, average depth, MC, ft & 13.1 & 13.5 & 12.4 \\
\hline Y1, average depth, LOB, ft & 2.1 & 2.4 & 1.4 \\
\hline$y 1$, average depth, ROB, ft & 0.8 & 1.2 & 0.2 \\
\hline Total conveyance, approach & 791568 & 848088 & 537465 \\
\hline Conveyance, main channel & 354248 & 370644 & 323341 \\
\hline Conveyance, LOB & 412695 & 432864 & 212417 \\
\hline Conveyance, ROB & 24625 & 44581 & 1706 \\
\hline Percent discrepancy, conveyance & 0.0000 & -0.0001 & 0.0002 \\
\hline Qm, discharge, $\mathrm{MC}$, cfs & 4564.8 & 5768.9 & 4048.8 \\
\hline Q1, discharge, LOB, Cfs & 5317.9 & 6737.3 & 2659.8 \\
\hline Qr, discharge, ROB, cfs & 317.3 & 693.9 & 21.4 \\
\hline $\mathrm{Vm}$, mean velocity $\mathrm{MC}$, ft/s & 2.9 & 3.6 & 2.7 \\
\hline Vl, mean velocity, LOB, ft/s & 0.5 & 0.6 & 0.3 \\
\hline Vr, mean velocity, ROB, ft/s & 0.4 & 0.7 & 0.2 \\
\hline Vc-m, crit. velocity, $\mathrm{MC}, \mathrm{ft} / \mathrm{s}$ & 0.8 & 0.8 & 0.8 \\
\hline VC-1, crit. velocity, LOB, ft/s & ERR & ERR & ERR \\
\hline Vc-r, crit. velocity, ROB, ft/s & ERR & ERR & ERR \\
\hline
\end{tabular}

Results

Live-bed(1) or Clear-Water(0) Contraction Scour? Main Channel 
Live-Bed Contraction scour

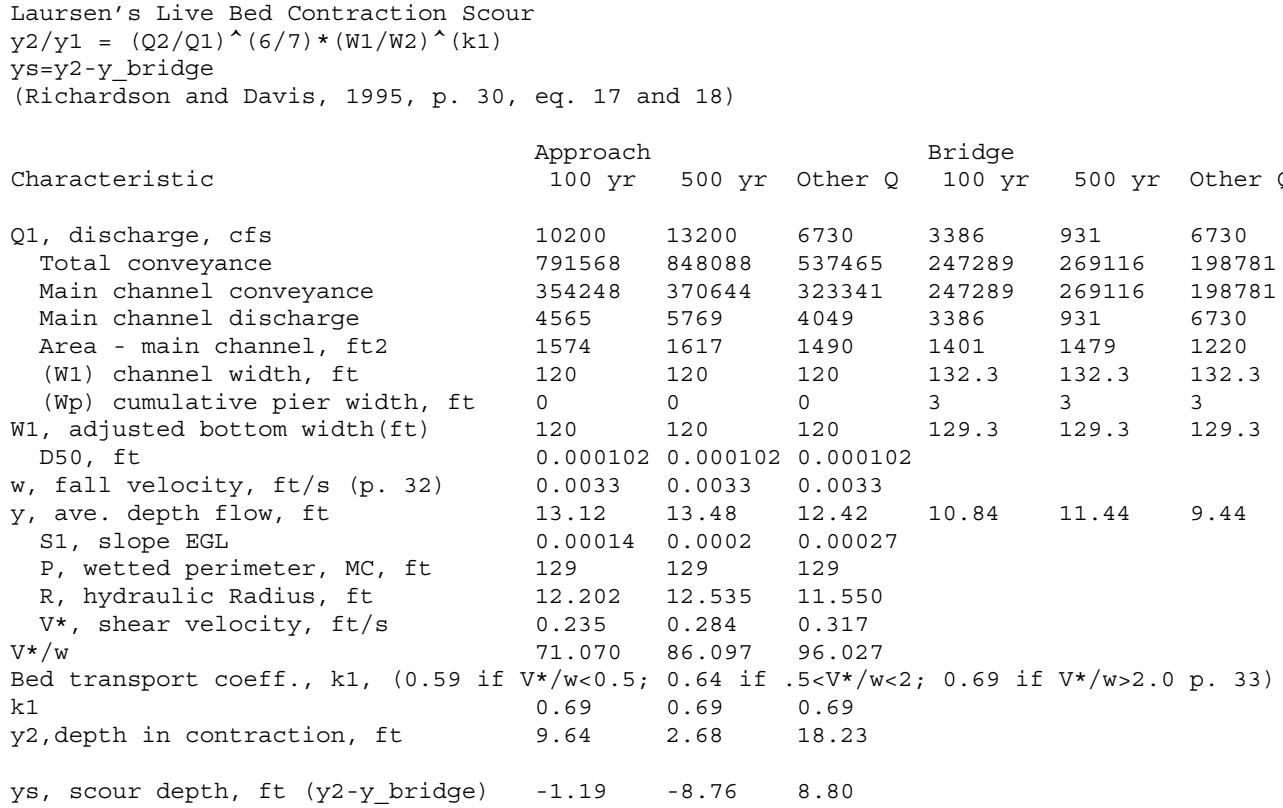




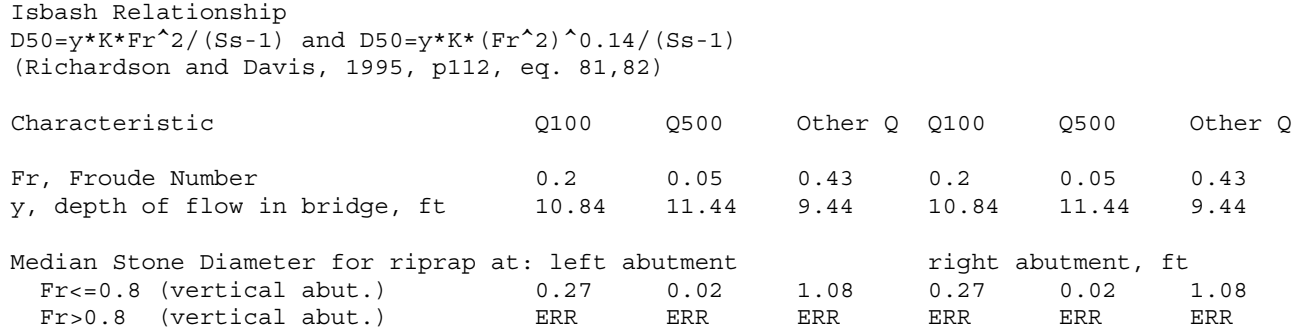

Pier Scour

$\mathrm{ys} / \mathrm{Y} 1=2.0 * \mathrm{~K} 1 * \mathrm{~K} 2 * \mathrm{~K} 3 * \mathrm{~K} 4 *(\mathrm{a} / \mathrm{Y} 1)^{\wedge} 0.65 * \mathrm{Fr} 1^{\wedge} 0.43$

(Richardson and Davis, 1995, p. 36, eq. 21)

K1, corr. factor for pier nose shape

Sharp nose, 0.9; round nose, cylinder, or cylinder grp., 1.0; square nose, 1.1

K2, corr. factor attack angle (see Table 3, p 37)

$\mathrm{K} 2=[\cos (\text { attackangle })+\mathrm{L} / \mathrm{a} * \sin (\text { attackangle })]^{\wedge} 0.65$

K3, corr. factor for bed condition

Clear-water, plane bed, antidune, 1.1; med. dunes, 1.1-1.2 (see Tab.4,p37)

K4, corr. factor for armoring (the following equations are in Si units)

$\mathrm{K} 4=\left[1-0.89 *(1-\mathrm{Vr})^{\wedge} 2\right]^{\wedge} 0.5$

$\mathrm{Vr}=(\mathrm{V} 1-\mathrm{Vi}) /(\mathrm{VC} 90-\mathrm{Vi})$

$\mathrm{V} 1=0.645 *((\mathrm{D} 50 / \mathrm{a}) \wedge 0.053) * \mathrm{VC} 50$

$\mathrm{VC}=6.19 *\left(\mathrm{Y}^{\wedge} 1 / 6\right) *\left(\mathrm{DC}^{\wedge} 1 / 3\right)$

Note for round nose piers:

ys $<=2.4$ times the pier width (a) for Fr $<=0.8$

ys $<=3.0$ times the pier width (a) for Fr $>0.8$

\begin{tabular}{|c|c|c|c|}
\hline Pier 1 & Q100 & Q500 & Qother \\
\hline Pier stationing, ft & 67 & 67 & 67 \\
\hline Area of WSPRO flow tube, ft 2 & 58.4 & 61.2 & 50.6 \\
\hline Skewed width of flow tube, ft & 4 & 4 & 3.8 \\
\hline y1, pier approach depth, ft & 14.60 & 15.30 & 13.32 \\
\hline y1 in meters & 4.450 & 4.663 & 4.058 \\
\hline V1, pier approach velocity, ft/s & 2.9 & 0.76 & 6.65 \\
\hline a, pier width, ft & 3 & 3 & 3 \\
\hline $\mathrm{L}$, pier length, ft & 17.8 & 17.8 & 17.8 \\
\hline Fr1, Froude number at pier & 0.134 & 0.034 & 0.321 \\
\hline Pier attack angle, degrees & 30 & 30 & 30 \\
\hline K1, shape factor & 0.9 & 0.9 & 0.9 \\
\hline K2, attack factor & 2.39 & 2.39 & 2.39 \\
\hline K3, bed condition factor & 1.1 & 1.1 & 1.1 \\
\hline D50, ft & 0.000102 & 0.000102 & 0.000102 \\
\hline $\mathrm{D} 50, \mathrm{~m}$ & 0.000031 & 0.000031 & 0.00003 \\
\hline D90, ft & 0 & 0 & 0 \\
\hline $\mathrm{D} 90, \mathrm{~m}$ & 0 & 0 & 0 \\
\hline Vc50, critical velocity (D50), m/s & 0.250 & 0.252 & 0.246 \\
\hline Vc 90 , critical velocity (D90), m/s & 0.000 & 0.000 & 0.000 \\
\hline Vi, incipient velocity, m/s & 0.093 & 0.094 & 0.092 \\
\hline Vr, velocity ratio & -8.471 & -1.463 & -21.053 \\
\hline K4, armor factor & 0.70 & 0.70 & 0.70 \\
\hline ys, scour depth (K4 applicable) ft & $\mathrm{ERR}$ & ERR & ERR \\
\hline ys, scour depth (K4 not applied)ft & 10.42 & 5.90 & 14.71 \\
\hline
\end{tabular}

Pier rip-rap sizing

$\mathrm{D} 50=0.692(\mathrm{~K} * \mathrm{~V})^{\wedge} 2 /(\mathrm{Ss}-1) * 2 * \mathrm{~g}$

(Richardson and Davis, 1995, p.115, eq. 83)

Pier-shape coefficient $(\mathrm{K})$, round nose, 1.5 ; square nose, 1.7 Characteristic avg. channel velocity, $\mathrm{V},(\mathrm{Q} / \mathrm{A})$ :

(Mult. by 0.9 for bankward piers in a straight, uniform reach,

up to 1.7 for a pier in main current of flow around a bend)

Pier 1

$\mathrm{K}$, pier shape coeff.

$\mathrm{V}$, velocity on pier, ft/s

Q100 Q500 Qother

$3.304 \quad 1.5 \quad 1.5$

D50, median stone diameter, ft

$\begin{array}{lll}0.16 & 0.01 & 0.87\end{array}$

